\title{
Strain-transcending neutralization of malaria parasite by antibodies against Plasmodium falciparum enolase
}

Sneha Dutta 1,3, Aneesha Tewari ${ }^{1,4}$, Chinthapalli Balaji ${ }^{1}$, Reena Verma ${ }^{1}$, Anasuya Moitra ${ }^{1}$, Mamta Yadav², Prakhar Agrawal ${ }^{2}$, Dinkar Sahal ${ }^{2}$ and Gotam K. Jarori ${ }^{1^{*}}$ (D)

\begin{abstract}
Background: Plasmodium enolase is a target for the growth neutralizing antibodies. Interestingly, the three invasive stages i.e. sporozoites, merozoites, and ookinetes express this protein on their cell surface. Polyclonal anti-Plasmodium falciparum enolase (Pfeno) antibodies disrupt traversal of ookinete through mosquito mid-gut wall as well as have inhibitory effect on parasite growth at erythrocytic stage. In a recent study, it was observed that immunization with a unique epitope of parasite enolase (EWGWS) could confer partial protection against mouse malaria. Further validation is needed for the protective potential of this unique epitope in otherwise highly conserved enolase.
\end{abstract}

Methods: In order to investigate the efficacy of growth inhibitory potential of the epitope of $P$ falciparum enolase, a monoclonal antibody specific to EWGWS is generated. In vitro parasite growth inhibition assays and passive immunization of Plasmodium yoelii (or Plasmodium berghei) infected mice were used to assess the parasite growth neutralizing activity of the antibody.

Results: Screening a panel of monoclonal antibodies raised against recombinant Pfeno that were specific to EWGWS resulted in isolation of H12E1. This antibody recognized only EWGWS epitope containing enolases. H12E1 strongly inhibited parasite growth in culture. This inhibition was strain transcending. Passive infusion of this antibody in $P$. yoelii or $P$. berghei infected mice showed significant reduction in parasitemia as compared to controls $(p<0.001)$. Surface Plasmon Resonance measurements indicated high affinity binding of H12E1 to P. falciparum enolase $\left(K_{D} \sim 7.6 \times 10^{-9} M\right)$.

Conclusions: A monoclonal antibody directed against EWGWS epitope of Pfeno was shown to inhibit the growth of blood stage malarial parasites. This inhibition was species/strain transcending and is likely to arise due to blockade of enolase on the surface of merozoites, functionally implicating Pfeno in invasion related events. Presence of enolase on the cell surface of merozoites and ookinetes could potentially result in inhibition of host cell invasions at erythrocytic and transmission stages in the parasite life cycle. It is suggested that antibodies against EWGWS epitope have the potential to confer dual stage, species and strain transcending protection against malaria.

Keywords: Plasmodium, Enolase, Protective epitope, Monoclonal antibodies, Growth inhibition, Merozoites, Malaria vaccine

\footnotetext{
*Correspondence: gkjarori@gmail.com

1 Department of Biological Sciences, Tata Institute of Fundamental

Research, Homi Bhabha Road, Colaba, Mumbai, India

Full list of author information is available at the end of the article
} 


\section{Background}

Despite recent progress in malaria prevention and control, the disease continues to take a heavy toll [1]. It is believed that the development of a malaria vaccine, which is effective over a wide range of human populations and covers a vast genetic diversity of the parasite, would be essential for complete eradication of malaria. At present, the best available vaccine is RTS,S/AS01, which received a positive opinion from European regulators for the first time in 2015 [2], is a pre-erythrocytic vaccine that targets sporozoites and protects by curtailing liver infection [3]. In recent field trials, this vaccine had shown modest efficacy in protection [4-6] and is unlikely to meet the goals for complete eradication of malaria. Efforts to develop a vaccine against the asexual blood stages of the parasite (which causes the clinical symptoms of the disease and against which natural immunity evolves) have led to identification of several antigens that could induce protective response. Some of these have been tested for their protective activity without much success [7-12]. Two major hurdles in the path for the development of a blood stage vaccine have been the presence of a high degree of antigenic polymorphism in the parasite and the high threshold levels of antibodies needed for protection [13, 14]. Plasmodium, being an intracellular parasite, needs to invade host cells to establish infection. There are three invasive stages (sporozoites, merozoites, ookinetes) in the life cycle of Plasmodium, two of which (sporozoites and merozoites) get briefly exposed to the humoral branch of the human immune system, rendering the molecular machinery of merozoites and sporozoites involved in invasion as attractive targets for anti-malarial vaccine.

Current approaches to circumvent the barriers imposed by the genetic diversity in Plasmodium and its multistage complex life cycle are to combine multiple antigens that are valid targets at various stages in the parasite life cycle as well as their orthologues from different species/ strains to obtain an effective multistage, species and strain transcending malaria vaccine [15-17]. An alternative approach will be to identify antigens or epitopes that have cell surface expression at multiple stages, do not exhibit polymorphism, have critical non-redundant physiological function(s) and have high immunogenicity.

Pfeno has recently been identified to be a target of parasite neutralizing antibodies. This antigen is unusual in exhibiting cell surface expression at all the three invasive stages [18-20]. Structurally, Pfeno is distinct from the host (human and mosquito) enolases in having a plant-like insert, EWGWS [21, 22]. Enolase in merozoites and ookinetes is a target for parasite neutralizing antibodies [19, 20, 23]. Anti-rPfeno antibodies showed strong growth inhibitory effect on blood stage in vitro cultures of Plasmodium falciparum. Antibodies induced by active immunization with rPfeno resulted in significantly reduced parasitemia that prolonged the survival of the infected mice [20]. These mice had a large fraction of their IgGs targeted against the EWGWS epitope of parasite enolase [24]. Immunization with a peptide containing EWGWS epitope also resulted in control of parasitemia. Antibody titers in EWGWS immunized animals showed a positive correlation with survival and a negative correlation with parasitemia [23]. Partial protection observed in immunized mice suggested that either the induced antibodies were at sub-threshold levels (poor immunogenicity) or there was a functional redundancy in the invasion step at which enolase was involved. Here, a monoclonal antibody based approach is taken to obtain further insight and assess the merozoite invasion neutralizing potential of the antibody directed against EWGWS epitope.

\section{Methods \\ Materials}

Protein A-Sepharose was obtained from Thermo Scientific, Rockford, IL, USA. ABTS was supplied by SigmaAldrich, St. Louis, MO, USA. Synthetic peptides were supplied by USV India Ltd., Mumbai, India. All the chemicals used were of analytical grade. Halobacterium gas vesicle nanoparticles (wild type and recombinant) were prepared as described earlier [23]. Recombinant particles had a peptide with a sequence ASKNEWGWSKSKS cloned in one of the gas vesicle proteins (gvpC).

\section{Purification of rPfeno and activity measurements}

rPfeno was purified using the over expression system as described earlier [21]. Briefly, full-length enolase gene was cloned from a gametocytic cDNA library made from NF54 strain of P. falciparum. The cloned gene was over expressed in E. coli BL21 and the 6XHis tagged recombinant protein was purified using Ni-NTA metal affinity chromatography. Cloning resulted in addition of 18 aminoacid residues (MRGSHHHHHHGSACELGT-) to the $\mathrm{N}$-terminus and 7 residues (-LQPSLIS) to the $\mathrm{C}$-terminus. Enolase activity was measured using 2-phosphoglycerate (2-PGA) as the substrate and monitoring the formation of phosphoenolpyruvate by increase in OD at $240 \mathrm{~nm}$. The assay mixture consisted of $500 \mu \mathrm{l}$ of $50 \mathrm{mM}$ Tris- $\mathrm{HCl} \mathrm{pH} 7.5,1.5 \mathrm{mM} \mathrm{Mg(II)}$ and $1.5 \mathrm{mM}$ 2-PGA [24].

\section{Generation of mouse mAbs against rPfeno}

For the generation of mAbs directed against various epitopes of rPfeno, 6 weeks old, female BALB/c mice were injected intraperitoneally with $50 \mu \mathrm{g}$ of purified rPfeno emulsified with Freund's complete adjuvant. This was followed by booster injections at an interval of 
3 weeks for the next 2 months. The best responder mouse was immunized with $250 \mu \mathrm{g}$ of immunogen (rPfeno) in phosphate buffer saline (PBS) (10 mM Na-Phosphate, $137 \mathrm{mM} \mathrm{NaCl}, 2.7 \mathrm{mM} \mathrm{KCl}, \mathrm{pH}$ 7.4). Five days later, the splenocytes from this mouse were fused with mouse myeloma SP2/O-Ag14 cells (Sigma-Aldrich) using polyethylene glycol (Merck) as fusogen. After selection in medium containing Hypoxanthine-Aminopterin-Thymidine (HAT, Invitrogen) for a week, the resulting hybrid clones were screened for antibody secretion wherein binding of hybridoma cell culture supernatants to rPfeno was tested by ELISA. Of the fifty seven hybrid clones that showed reactivity to rPfeno in ELISA, thirty four were re-cloned by limiting dilution to obtain pure clones. Generation of hybridomas and production of hybridoma supernatants were carried out by Bioklone Biotech Pvt. Ltd, Chennai, India.

\section{Purification and isotyping of $m A b s$}

mAbs from the hybridoma supernatants were purified using the ammonium sulfate precipitation method [25]. Briefly, the IgG (mAb) was precipitated from hybridoma supernatant by adding powdered ammonium sulfate to $45 \%$ saturation using standard protocol. The precipitate was collected by centrifugation, dissolved in phosphate saline buffer (PBS) and dialyzed to remove the salt. The dialyzed solution was passed through a Protein-A affinity column (Thermo Scientific Pierce 20356) and eluted with a low $\mathrm{pH}$ buffer $(0.1 \mathrm{M}$ glycine- $\mathrm{HCl}, \mathrm{pH} 2.0)$. Alternatively, the ascites fluid was filtered through glass wool and $\sim 15 \mathrm{ml}$ filtrate was passed through $5 \mathrm{ml}$ Protein-A Sepharose column. The flow through was collected and stored for later testing of any unbound residual antibody. The column was washed with three column volumes of PBS. Following this, $5 \mathrm{ml}$ of elution solution $(0.1 \mathrm{M}$ glycine- $\mathrm{HCl} \mathrm{pH} \mathrm{2.0)} \mathrm{was} \mathrm{added} \mathrm{and} 1 \mathrm{ml}$ fractions of the eluate were collected. Each $1 \mathrm{ml}$ fraction was neutralized with $100 \mu \mathrm{l}$ of $1 \mathrm{M}$ Tris, $\mathrm{pH}$ 9.0. $10 \mu \mathrm{l}$ of each of the five aliquots, dissolved in Laemmli buffer [26], were run on a $10 \%$ SDS-PAGE to evaluate the purity of the preparation. IgGs were also purified from anti-rPfeno antisera (polyclonal) as well as pre-immune sera using ammonium sulfate precipitation and Protein A affinity chromatography as described above. Purified IgGs were sterilized by filtration through a $0.22-\mu \mathrm{m}$ filter and the solution was tested in LB medium for any bacterial contamination.

For determining the IgG subtype of $\mathrm{mAb}, 100 \mu \mathrm{l}$ of goat antibodies to mouse isotypes viz., IgG1, IgG2a, IgG2b, IgG3, IgM and IgA were coated in the wells of a microtitre plate at 1:1000 dilution. Following this, the hybridoma culture fluid containing anti-rPfeno $\mathrm{mAb}$ was added and incubated overnight at $4{ }^{\circ} \mathrm{C}$. Mouse anti-rPfeno serum (1:1000) was used as positive control. The wells were later treated with rabbit anti-mouse IgG-HRP (that binds to mouse IgG, IgM and IgA) and ABTS substrate was added to measure reactivity at $405 \mathrm{~nm}$ [21]. The OD values obtained for the positive control were IgG1: 0.61 ; IgG2b:0.69; IgG3:0.57; IgM:2.24; IgA:0.93 indicating the ability of secondary antibody to bind to all three immunoglobulins. Isotyping of mAbs was performed by Bioklone Biotech Pvt. Ltd, Chennai, India.

\section{ELISA}

ELISA was performed as described earlier [20]. Briefly, wells in immunoplates (Nunc, Denmark) were coated with 50-100 ng of purified $\mathrm{rPfeno}$ and incubated at $37^{\circ} \mathrm{C}$ for $2 \mathrm{~h}$. After a single wash, the wells were blocked by the addition of 5\% skimmed milk in PBST (phosphate buffer saline containing $0.05 \%$ Tween-20, $\mathrm{pH}$ 7.4) and incubated for $1 \mathrm{~h}$ at room temperature or $4{ }^{\circ} \mathrm{C}$ overnight. The blocking solution was discarded and the wells were washed with PBST 3 times for 5 min each. The wells were then coated with $100 \mu \mathrm{l}$ of primary antibody (dilution varied according to experiment) and incubated at room temperature for $1 \mathrm{~h}$. The solution was discarded and the wells were washed with PBST three times to remove any unbound antibody. This was followed by coating the wells with HRP conjugated mouse secondary antibody at a dilution of 1:1000 and incubating it at room temperature for $45 \mathrm{~min}$. The solution was discarded and the wells were washed with PBST thrice; $200 \mu \mathrm{l}$ of ready-to-use ABTS substrate was added into each well. The colour was allowed to develop for 10-15 min and the OD was measured at $405 \mathrm{~nm}$ on a Tecan Plate Reader.

For a competitive ELISA, a cyclized 13-mer peptide with a sequence $\mathrm{NH}_{2}$-SCKNEWGWSKSCS-COOH (CPS1920) containing EWGWS was synthesized. ELISA plates were coated with $50 \mathrm{ng}$ of rPfeno ( $1 \mathrm{pmol}) ; 100 \mu \mathrm{l}$ of buffer containing $1 \mathrm{pmol}$ of antibody and different concentrations of CPS1920 peptide $(0,5,10$ and $100 \mu \mathrm{M})$ were incubated overnight at $20{ }^{\circ} \mathrm{C}$. Pre-incubated peptide plus $\mathrm{mAb}$ was then added to the ELISA plate wells in triplicates and incubated for $10 \mathrm{~min}$ and the plates were developed using the ABTS substrate as described above. An irrelevant peptide $\mathrm{NH}_{2}$-SWPLPSHTAVWG-COOH (Peptide CPS1916-1) was used in place of CPS1920 as a control to ensure specificity of competitive displacement.

\section{SDS-PAGE and western blotting}

Proteins were resolved on a 10 or $12 \%$ SDS-PAGE [26] and visualized by staining with Coomassie Brilliant Blue R-250. For Western blotting, proteins separated by SDSPAGE were transferred to a PVDF membrane using semi-dry western transfer apparatus (Trans-blot SD-cell, Bio-Rad Laboratories, Inc., Hercules, CA, USA) at a constant voltage of $18 \mathrm{~V}$ for $50 \mathrm{~min}$. The membranes were 
blocked with 5\% skimmed milk in PBST for $2 \mathrm{~h}$. The blots were treated with primary antibody followed by washing and incubation with HRP conjugated secondary antibody. The immunoblots were developed using ECL substrate (Pierce).

\section{In vitro culture and synchronization of Plasmodium falciparum 3D7}

Plasmodium falciparum 3D7 was cultured as described earlier [27]. Fresh human RBCs were obtained from the blood samples drawn from consenting informed volunteers by a professional at the Pathology Department, Health Promotion Facility of Tata Institute of Fundamental Research, Mumbai, India.

The ring stage parasite cultures were synchronized by sorbitol treatment as described earlier [28]. Briefly, 5\% sorbitol was added to the infected RBC pellet and incubated at $37{ }^{\circ} \mathrm{C}$ for $10 \mathrm{~min}$ followed by centrifugation (1500 g, $5 \mathrm{~min}$ ). The cells in the pellet were cultured for $48 \mathrm{~h}$ (i.e., one cycle of multiplication) before subjecting them to a second round of sorbitol treatment. Such a double sorbitol treatment resulted in a high degree of synchrony ( $>98 \%$ ring stage parasites) [29].

\section{Growth inhibition assays}

Asexual stages of $P$. falciparum 3D7 were cultured in vitro [30] and growth/invasion inhibition assay was performed on a 96-well plate as described earlier [16, 20, 31]. Plasmodium falciparum 3D7 cultures maintained on $\mathrm{O}^{+}$erythrocytes at $2 \%$ haematocrit were synchronized at the ring stage using sorbitol treatment [29]. For each assay, $200 \mu \mathrm{l}$ of $0.5-3 \%$ parasitized cells were used in three identical wells for each time point or antibody concentration. The culture plates were incubated for $48 \mathrm{~h}$ and parasitemia was assessed by examining the culture smears using Field stain [32]. Percent parasitemia was determined by counting at least $>1000$ erythrocytes [20]. Differences in mean parasitemia between control (no $\mathrm{mAb}$ ) and experimental (mAb added) samples were analysed with Student's t-test using GraphPad (InStat, San Diego, CA, USA). Differences were considered significant if the p-values were $<0.05$.

For the data presented in Fig. 4, the following method was used to measure the GIA of the mAb. Chloroquine (CQ) sensitive (3D7) and resistant (INDO) strains of $P$. falciparum were used for in vitro cultures. Parasite strains were cultivated by the method of Trager and Jensen [33] with minor modifications. Cultures were maintained in fresh $\mathrm{O}^{+}$human erythrocytes (obtained from Rotary Blood Bank, 56-57, Tughlakabad Institutional Area, New Delhi, 110062). Cultures were maintained at $4 \%$ haematocrit in complete medium (RPMI 1640 with $0.2 \%$ sodium bicarbonate, $0.5 \%$ Albumax II,
$45 \mathrm{mg} / \mathrm{l}$ hypoxanthine, and $50 \mathrm{mg} / \mathrm{L}$ gentamicin) at $37{ }^{\circ} \mathrm{C}$ under reduced $\mathrm{O}_{2}$ (gas mixture $5 \% \mathrm{O}_{2}, 5 \% \mathrm{CO}_{2}$, and $90 \%$ $\left.\mathrm{N}_{2}\right)$. Stock solutions $(1 \mathrm{mM})$ of CQ were prepared in water (MilliQ grade), and lyophilized powders of antibodies were dissolved in filter sterilized MilliQ water to a final concentration of $1 \mathrm{mg} / \mathrm{ml}$. 0-6 $\mu \mathrm{l}$ antibody solutions were transferred to wells of microtitre plate taking each dose in triplicates and final volume was made to $6 \mu \mathrm{l}$ in each well using PBS. Chloroquine $(1 \mu \mathrm{M})$ was used as positive control. Ring stage Sorbitol synchronized culture $(94 \mu \mathrm{l})$ was aliquoted to wells of 96-well plate at $2 \%$ haematocrit and $1 \%$ parasitemia in a final volume of $100 \mu \mathrm{l}$. After $48 \mathrm{~h}$ of incubation under standard culture conditions, plates were harvested and read by the SYBR Green I fluorescence-based method [34, 35] using a 96-well fluorescence plate reader (Victor, PerkinElmer), with excitation and emission wavelengths of 485 and $535 \mathrm{~nm}$, respectively. The fluorescence readings were plotted against antibody concentration and $\mathrm{EC}_{50}$ values were obtained by visual matching the mAb concentration corresponding to $50 \%$ growth inhibition. In cases where parasitemia was determined microscopically, $>2000$ cells were counted using Auto count software [36].

\section{Passive immunization}

Passive transfer of immunity was tested using 6-8 weeks old Swiss male mice. In two different experiments, mice were challenged either with $P$. yoelii 17XL or with $P$. berghei ANKA. Frozen stocks of parasite infected RBCs (pRBCs) were thawed and injected into the mice. The pRBCs obtained from the second round of passage were used to challenge the mice. In the first experiment (Fig. 5a), all mice (five animals in experimental group, three each in pre-immune and no IgG control groups) were administered with $\sim 10^{5} P$. yoelii $17 \mathrm{XL}$ infected pRBCs. On the same day, purified antibody $(0.75 \mathrm{mg}$ $\mathrm{H} 12 \mathrm{E} 1$ in $100 \mu \mathrm{l}$ ) was administered intravenously. Control groups were injected either with $0.75 \mathrm{mg}$ of preimmune IgGs or with $100 \mu \mathrm{l}$ of buffer.

In the second experiment (Fig. 5b), two groups of mice (five animals in experimental group and five in control group) were challenged with $\sim 10^{5} P$. berghei ANKA infected mouse pRBCs. H12E1 antibody $(1 \mathrm{mg}$ in $100 \mu \mathrm{l})$ was injected in experimental group of animals while the control group received $1 \mathrm{mg}$ of purified pre-immune IgGs. In both the experiments, thin blood smears were prepared (by obtaining blood via the tail bleeding method) every alternate day and the parasitemia was measured using Plasmodium Auto count software [36]. At each time point $>2000$ cells were counted. Percentage parasitemia was determined as an average of three samples and plotted with standard deviation at each time point. Differences in mean parasitemia between 
the control and experimental groups were analysed with Student's t-test as described above. If parasitemia rose to $\geq 50-60 \%$ and the mouse showed severe clinical symptoms, the animal was euthanized.

mAb-rPfeno interaction using Surface Plasmon Resonance Surface Plasmon Resonance (SPR) measurements were made using Biacore T20 machine version 2 control and evaluation software (GE Healthcare Life Sciences, Sweden) located at IIT, Mumbai. All measurements were made at $25{ }^{\circ} \mathrm{C}$. Running buffer consisted of $10 \mathrm{mM}$ HEPES containing $150 \mathrm{mM} \mathrm{NaCl}, 3 \mathrm{mM}$ EDTA and $0.005 \%$ (w/v) P20 surfactant, pH 7.4. rPfeno was immobilized covalently on the surface of CM5 sensor chip using amine coupling with the target response unit of 1000 Rmax. The process involving steps of activation, immobilization and blocking were carried out. Briefly, using a flow rate of $10 \mu \mathrm{l} / \mathrm{min}$, the chip surface was activated by injecting freshly prepared 1:1 mixture of EDC and NHS (both dissolved in water as per the manufacturer's instructions). Subsequently, $30 \mu \mathrm{g} / \mathrm{ml} \mathrm{rPfeno} \mathrm{in} 10 \mathrm{mM}$ sodium acetate ( $\mathrm{pH}$ 5.5) was passed through the active flow cell for $90 \mathrm{~s}$ at a flow rate of $30 \mu \mathrm{l} / \mathrm{min}$. The remaining activated carboxy methyl groups on the surface were blocked by a 7-min injection of $1 \mathrm{M}$-ethanolamine- $\mathrm{HCl}$, $\mathrm{pH}$ 8.5. An unmodified flow cell surface was used as a reference for each analysis to check for the non-specific binding response to dextran matrix.

For the measurement of kinetics of interaction between rPfeno and $\mathrm{mAb}$, the analyte (mAb H12E1) was diluted with HEPES buffer and injected over the rPfeno-immobilized chip for $90 \mathrm{~s}$ at a flow rate of $30 \mu \mathrm{l} / \mathrm{min}$ followed by a final $240 \mathrm{~s}$ dissociation phase. Several concentrations of analyte ranging between 0.78 and $100 \mathrm{nM}$ were used. Regeneration was done with $10 \mathrm{mM} \mathrm{NaOH}$ at a flow rate of $30 \mu \mathrm{l} / \mathrm{min}$ for $30 \mathrm{~s}$. Data were evaluated with BIA evaluation software (GE Healthcare Life Sciences, Sweden version 2.0). The sensograms obtained at each antibody concentration was fitted with 1:1 bivalent kinetics for both the association and dissociation phases. Equilibrium dissociation constant $\left(\mathrm{K}_{\mathrm{D}}\right)$ was then calculated from the dissociation and association rate constants.

\section{Molecular modelling}

3D-structure of Pfeno was modelled based on the X-ray crystallographic structure of $T$. gondii Enolase1 (TgENO1; PDB: 3OTR) [37] using the Automated Mode of Swiss Model PDB viewer 8.05 (http://swissmodel .expasy.org/). UniProt/Swiss-Prot database was used to obtain the amino acid sequence of Pfeno (UniProt Accession No. Q27727, 446 amino acids). Energy minimization of the optimized model structure was achieved using the software: MOE 2016.08 (Chemical Computing Group,
Canada). PyMOL 1.3 [38] was used to visualize the modelled structures.

\section{Results \\ Screening of hybridoma supernatants for EWGWS specific mAbs}

For the identification of $\mathrm{mAbs}$ that were directed against the EWGWS epitope in Pfeno, supernatants from 34 Pfeno-positive hybridoma clones were tested for their reactivity with WT-rPfeno and $\Delta^{5}$-rPfeno (a deletion variant lacking EWGWS) [24]. The difference in reactivity of mAbs between rPfeno and $\Delta^{5}$-rPfeno presumably reflected the selectivity towards the insert sequence. Ratio of the reactivities with the two forms ( $\mathrm{rPfeno} / \Delta^{5}$. rPfeno) was computed to identify the ones that were selective towards EWGWS. Figure 1a shows data for all hybridoma supernatants along with their reactivity ratios (rPfeno $/ \Delta^{5}$-rPfeno). There were three hybridoma supernatants that had $\sim$ six to seven-fold greater sensitivity towards WT-rPfeno compared to the deletion variant $\Delta^{5}$-rPfeno and were of high binding specificity to EWGWS. These mAbs, i.e., H12E1, H12B8 and B1B3 that had reactivity ratios of 7.4, 7.2 and 6.4, respectively, were all of the IgG2b type (Additional file 1).

As deletion of EWGWS dissociates dimeric rPfeno into monomers, there is a possibility that the observed low reactivity could arise from altered epitope structure of $\Delta^{5}$-rPfeno [24]. To rule out such a possibility, the reactivity of EWGWS-specific mAbs against another dimeric enolase that does not have the EWGWS insert sequence, namely yeast enolase (Yeno) was measured. Parallel ELISA measurements were made using rPfeno and Yeno as antigens. As shown in Fig. 1b, all three antibodies showed high reactivity towards rPfeno compared to Yeno. EWGWS containing rPfeno had 4.2-5.5-fold greater reactivity than Yeno that lacked the insert. In the initial experiments, all three mAbs were tested for their binding specificity and ability to inhibit parasite growth in culture. Since, most reproducible results in multiple such assays were obtained with $\mathrm{H} 12 \mathrm{E} 1$, all subsequent experiments were performed using H12E1 antibody only.

\section{Western analysis of whole cell extracts using H12E1 antibody}

To assess whether the H12E1 antibody exclusively recognizes only the EWGWS containing enolases, whole cell extracts of Plasmodium yoelii, Plasmodium berghei, Toxoplasma gondii, Brassica spp., Arabidopsis thaliana and human embryonic kidney cells (HEK293T) were subjected to western analysis using H12E1 mAb. The deletion variant $\Delta^{5}$-rPfeno was also included as a negative control lacking the EWGWS insert. The resulting blot showed a positive signal at $50 \mathrm{kDa}$ in, $P$. yoelii, $P$. 


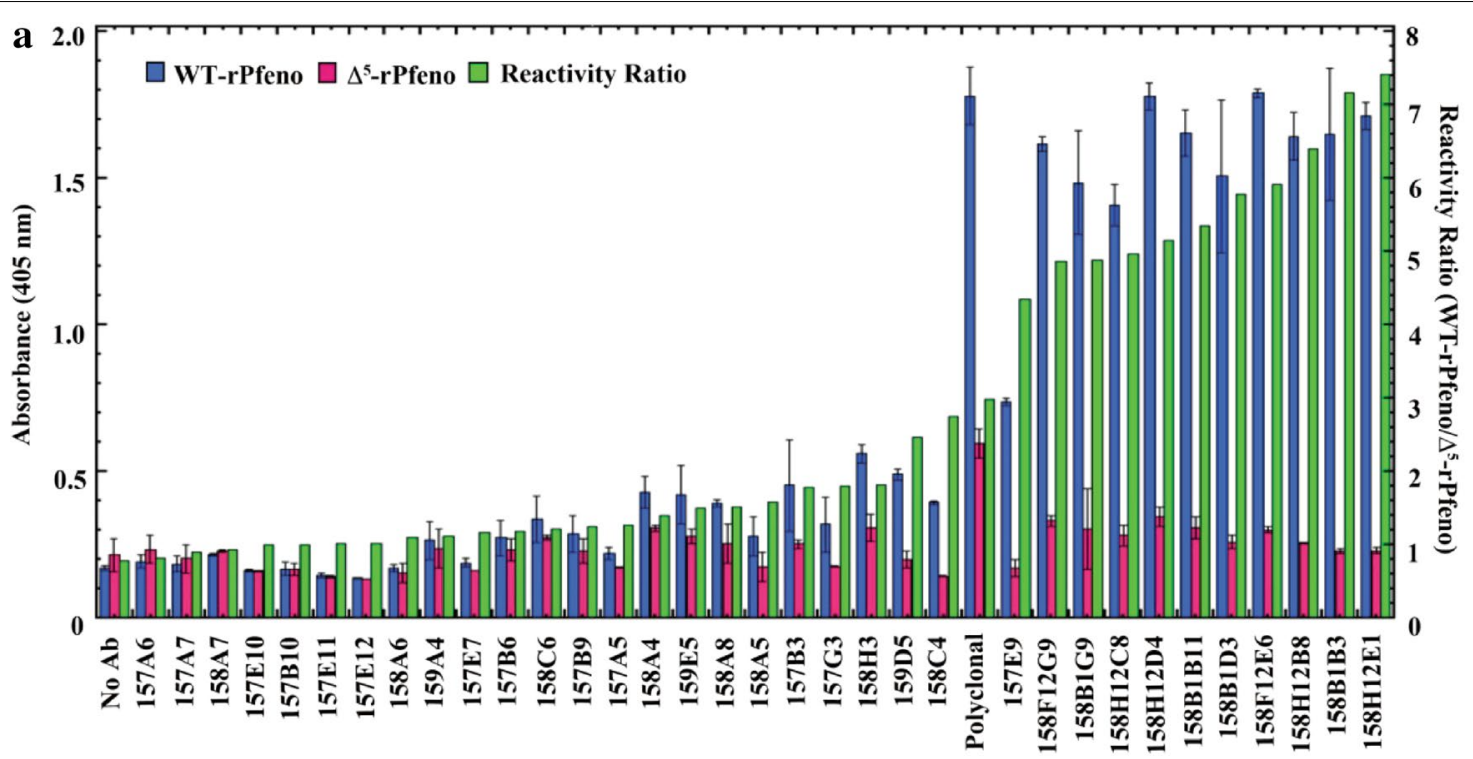

b

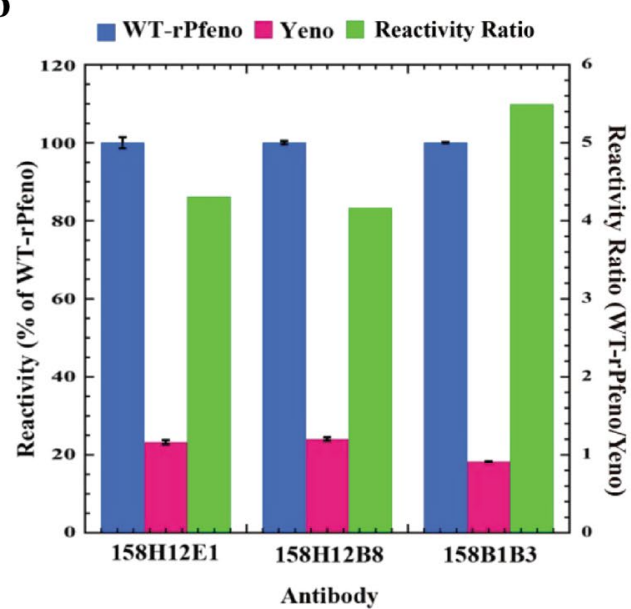

c
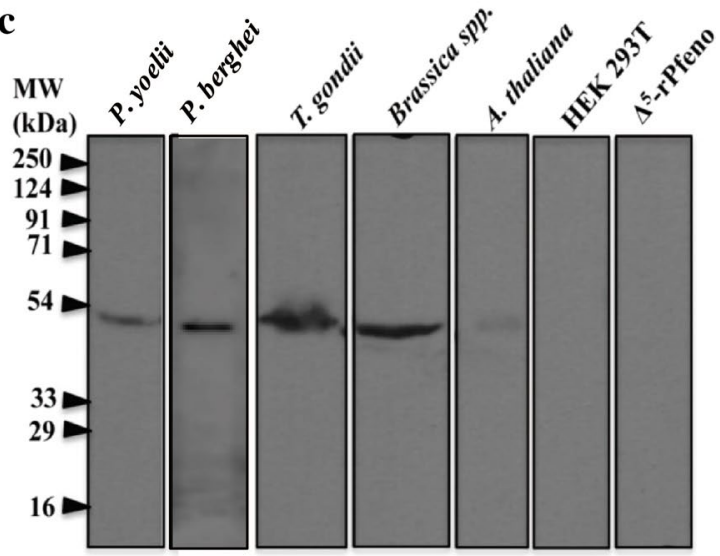

Fig. 1 Screening of mAbs that are specific to the EWGWS epitope in Pfeno. a Reactivity of mAbs with WT-rPfeno and $\Delta^{5}$-rPfeno as measured by ELISA. Reactivity ratio (green bars) is defined as the ratio of the two reactivities, i.e., O.D.WT-rpfeno/O.D. $\Delta 5$-rPfeno. b Reactivity of anti-rPfeno monoclonal antibodies with yeast enolase that lacks the insert sequence. Three mAbs with high reactivity ratio namely $\mathrm{H} 12 \mathrm{E} 1, \mathrm{H} 12 \mathrm{~B} 8$ and B1 B3 were used in this ELISA. c Western blot analysis of cell lysates from different organisms (P. yoelii, P. berghei, Toxoplasma gondii, Brassica spp., Arabidopsis thaliana, Human Embryonic Kidney cells (HEK 293T) and $\triangle^{5}$-rPfeno). Blot was probed using anti-rPfeno mAb H12E1. Antibody reactivity is observed only for the enolases containing the EWGWS motif. Enolases lacking this insert (HEK 293T and $\triangle^{5}$-rPfeno) did not show any reactivity

berghei, Toxoplasma gondii, Arabidopsis thaliana and Brassica spp. (Figure 1c). Lanes containing HEK 293T cell extract and purified $\Delta^{5}$-rPfeno had no H12E1 reacting band. There were no other cross-reacting proteins in any of the cellular extracts indicating exclusive reactivity of the H12E1 to EWGWS epitope in enolases (Fig. 1c).

\section{Effect of insert sequence variation on binding of $m A b$ with rPfeno}

The effect of varying the insert sequence in Pfeno on binding of H12E1 was examined by monitoring the extent of antibody reactivity with different variants. Figure 2a shows the sequence changes made in these variants using site directed mutagenesis [21, 24, 39, 40]. Replacement of S108 with glycine (S108G-rPfeno) had no effect on antibody binding. However, altering the two tryptophan residues (W105 and W107) significantly reduced the binding ability of the variants with the mAb (Fig. 2b). These variants differ from each other in their oligomeric structure as well as in enzymatic activity. WT and S108G-rPfeno are enzymatically active and dimeric while the other three variants 


\section{$\mathbf{a}$}
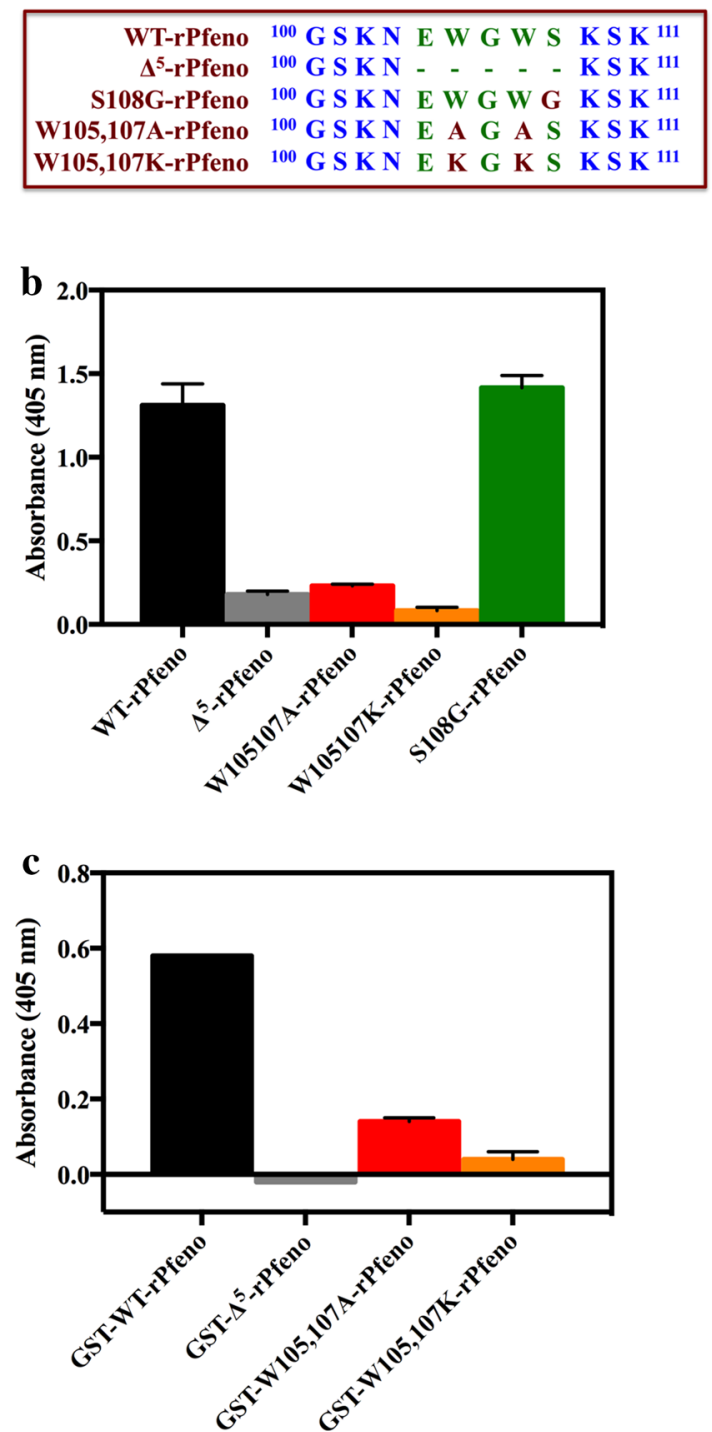
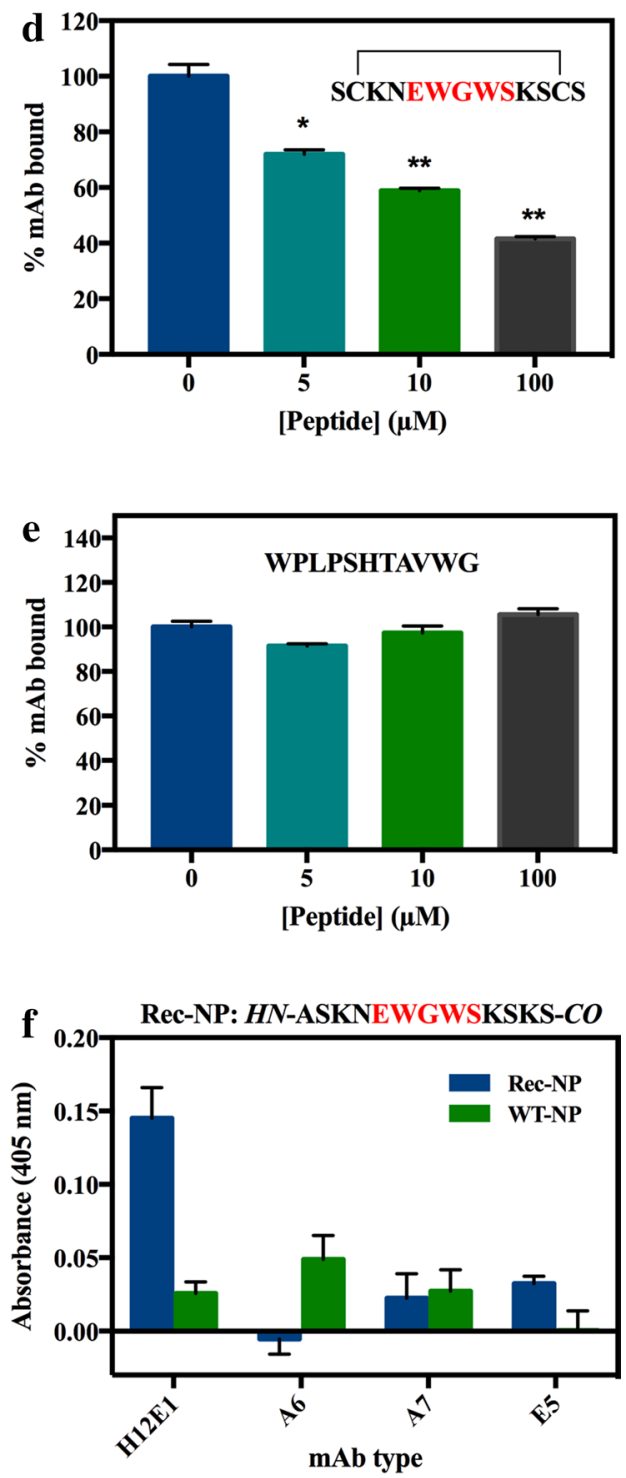

Fig. 2 Antigenic specificity of $\mathrm{mAb}$ H12E1. a Sequences of pentapeptide insert in different variants. $\mathbf{b}$ ELISA of mAb binding to different variants of rPfeno. Oligomeric state of WT and S108G-rPfeno was dimeric while $\Delta^{5}$-rPfeno, W105, 107K-rPfeno and W105, 107A-rPfeno were in the monomeric form. $15 \mathrm{ng}$ of purified protein of each variant form was coated on the plates. c ELISA of mAb binding to GST-tagged forms of rPfeno variants. In GST-tagged forms, all variants of rPfeno formed dimers (or higher oligomers). Wells were coated with $5 \mathrm{ng}$ of purified protein of each variant. Variation in insert sequence affected the mAb binding while oligomeric state (monomer or dimer Pfeno) did not have any effect on reactivity. $\mathbf{d}$ Competitive ELISA with EWGWS containing peptide led to displacement of H12E1 from rPfeno. Peptide concentration was varied from 0-100 $\mu \mathrm{M}$. e Titration with an irrelevant peptide epitope resulted in no displacement of the mAb by the irrelevant peptide. $\mathbf{f}$ Reactivity of various mAbs with WT-NPs and Rec-NPs. mAb directed against EWGWS i.e. H12E1 showed strong reactivity to the EWGWS containing Rec-NPs (incorporated with a clone peptide sequence ASKNEWGWSKSKS) as compared to WT-NPs

are monomeric and largely inactive $[24,39,40]$. To rule out the possibility that non-reactivity of the $\Delta^{5}$-rPfeno and Trp variants (W105, 107A-rPfeno and W105, $107 \mathrm{~K}-\mathrm{rPfeno}$ ) was due to the altered oligomeric structure of the protein, an ELISA was performed on the GST-tagged forms of the different variants. In the GST tagged form, all these variants form dimers (or oligomers) and acquire active conformation [24, 39]. ELISA data presented in Fig. $2 c$ indicated that stabilization of $\Delta^{5}$-rPfeno and the Trp variants as dimers did not improve their ability to bind to the antibody. Loss of H12E1 binding to rPfeno variants with altered insert sequence suggests that this antibody is specific for EWGWS. 


\section{Competitive displacement of rPfeno by EWGWS-containing peptide}

In a competitive ELISA experiment, the ability of an EWGWS sequence containing peptide $\mathrm{NH}_{2}$-SCKNEWGWSKSCS-COOH (cyclized by a disulfide bond) to compete with rPfeno, for binding to H12E1 was examined. With increasing concentrations of the peptide, there was a gradual decrease in the amount of H12E1-rPfeno complex formed. At the highest concentration of the peptide used, a decrease of $45-50 \%$ in the binding of H12E1 was observed (Fig. 2d). Similar titration using an irrelevant peptide $\mathrm{NH}_{2}$-SWPLPSHTAVWG-COOH failed to compete with rPfeno for binding to the mAb (Fig. 2e). The observed competitive reduction in the amount of the bound $\mathrm{mAb}$ to rPfeno with increasing concentration of the peptide reflects the specific binding of mAb to EWGWS.

\section{Recognition of EWGWS by mAb H12E1}

Further evidence for the binding specificity of H12E1 with EWGWS was obtained by measuring the reactivity of the antibody to the wild type (WT-NP) and recombinant nanoparticles (Rec-NP) [23]. These particles that were derived from Halobacterium gas vesicles had a peptide sequence ASKNEWGWSKSKS containing EWGWS cloned in one of its component proteins gvpC (Rec-NP). In an experiment where ELISA plates were coated with WT-NPs and Rec-NPs, reactivity of H12E1 and three other mAbs (A6, A7 and E5) that did not show any selectivity between wild type rPfeno and $\Delta^{5}$-rPfeno, was measured. ELISA values obtained with WT-NP and
Rec-NP are shown in Fig. 2f. H12E1 showed $~ 7-8$ times higher reactivity with Rec-NPs as compared to WT-NPs. Three other mAbs that were not specific for-EWGWSdid not show any reactivity with the two classes of the nanoparticles.

H12E1 mAb's ability to discriminate between rPfeno and $\Delta^{5}$-rPfeno as well as the positive recognition of the peptides containing EWGWS were indicative of its high binding specificity to the unique epitope (EWGWS) of the parasite enolase.

\section{Growth inhibitory activity (GIA) of anti-enolase antibodies}

Effect of various antibodies on in vitro growth was measured in a growth/invasion inhibition assay. Addition of polyclonal anti-rPfeno antibodies and hybridoma supernatant from $\mathrm{H} 12 \mathrm{E} 1$ at different dilutions on parasite growth is shown in Fig. 3a. Results obtained here were consistent with an earlier report [20] where $~ 50 \%$ inhibition in parasitemia was observed for the polyclonal anti-rPfeno antibody at 1:100 dilution. The observed inhibitory effect of H12E1 supernatant (1:10 and 1:100) treated samples was very potent. It showed almost complete inhibition of growth (Fig. 3a).

The possibility of such strong inhibition arising due to the presence of some toxicant in the hybridoma supernatant was considered. To rule out such a possibility, IgGs were purified and filtered through $0.22 \mu \mathrm{m}$ filter to eliminate all components of hybridoma culture medium. The antibody solution was tested in LB medium to rule out the possibility of any bacterial contamination. Another experiment was performed using purified IgGs. In this
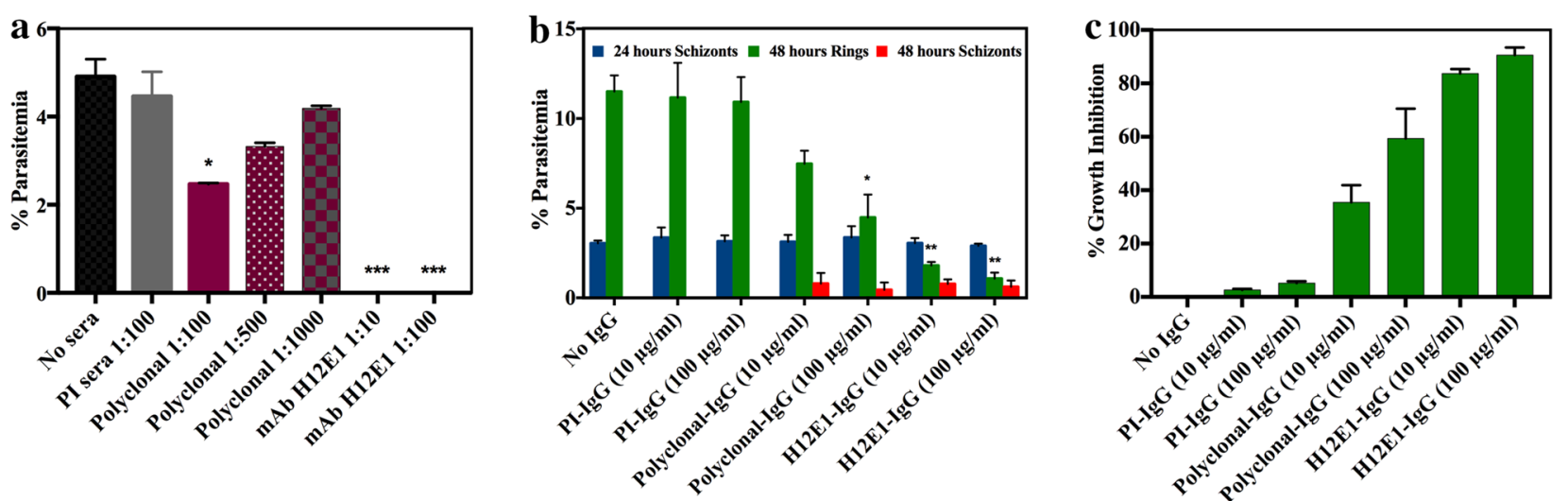

Fig. 3 Growth inhibitory activity (GIA) of anti-Pfeno antibodies. a Effect of polyclonal anti-rPfeno sera and mAb H12E1 hybridoma supernatant on in vitro growth of P. falciparum 3D7.'Pre-immune (PI) serum' and 'no serum'samples served as controls. Cultures were allowed to grow for $48 \mathrm{~h}$ before determining the \% parasitemia. Initial parasitemia was $0.5 \%$. b Effect of purified lgGs on parasite growth. Initial parasitemia was $3.2 \%$. \% parasitemia was determined at 24 (blue bars) and $48 \mathrm{~h}$ (green and red bars). At the 24-h time point all the samples had only schizonts. At $48 \mathrm{~h}, \mathrm{no}$ IgG and pre-immune lgGs treated samples (contols) showed only ring stage parasites (green bars). Samples treated with polyclonal anti-rPfeno and H12E1 lgGs had rings (green bars) as well as schizonts (red bars) in parasitized cells. c \% growth inhibition by different lgGs. Significance of decrease in parasite growth in antibody treated samples was compared with control samples using Student's t-test. ${ }^{*} p<0.05,{ }^{* *} p<0.01$ and ${ }^{* * *} p<0.001$ 
experiment initial parasitemia was kept at $~ 3 \%$ and culture smears were prepared at 24 and $48 \mathrm{~h}$ post antibody addition, respectively. In the intra-erythrocytic asexual multiplication cycle, the parasite develops into a schizont from the mature ring stage in $\sim 24 \mathrm{~h}$. By $48 \mathrm{~h}$, mature schizonts would have released merozoites that would reinvade fresh red blood cells (RBCs) and form ring stage Plasmodia in infected RBCs. In smears prepared at the 24-h time point all samples showed only schizonts (blue bars in Fig. 3b). There were no ring stage parasites in any of the samples indicating that the ring to schizont stage transition was not affected by the treatment with polyclonal or monoclonal anti-rPfeno antibodies. At $48 \mathrm{~h}$ the smears of both the control samples (no serum and pre immune serum) showed abundance of ring stage parasites $(\sim 12 \%)$ without any schizonts. Enolase antibody treated samples had relatively fewer numbers of parasites indicating the inhibition of growth. Interestingly, these smears also had some un-ruptured schizonts $(\sim 15-30 \%$ of total schizont population at $24 \mathrm{~h}$ ) (Additional file 2). In case of H12E1 treated samples (IgG $\sim 10$ and $100 \mu \mathrm{g}$ / $\mathrm{ml}$ ), culture smears had very few rings and some mature unruptured schizonts $(\sim 15-30 \%$ of total schizont population at $24 \mathrm{~h}$ ) (Additional file 2). Quantitative data of ring and schizont stage parasites at 24 and $48 \mathrm{~h}$ for all the samples are shown in Fig. 3b. Data are also plotted as \% growth inhibition taking control parasite counts as $0 \%$ inhibition H12E1 antibody treated samples exhibited $\geq 90 \%$ inhibition in parasite growth (Fig. 3c).

\section{mAb concentration dependence of parasite growth inhibition}

For independent verification of the growth neutralizing properties of H12E1, growth inhibition assays were also performed in Dr. D. Sahal's laboratory at ICGEB, New Delhi, India. The dose dependence of growth inhibitory activity of H12E1 antibody along with two others (B1B3 and H12B8) was evaluated. Tightly synchronized ring stage parasites were treated with varying concentrations of purified mAbs $(0-60 \mu \mathrm{g} / \mathrm{ml})$. H12E1 mAb had a potent growth neutralizing effect with almost complete growth inhibition at $\sim 50-60 \mu \mathrm{g} / \mathrm{ml}$ with $\mathrm{EC}_{50} \sim 21.3 \pm 2.1 \mu \mathrm{g} /$ $\mathrm{ml}$. In a parallel measurement, effect of H12E1 was also determined by measuring $\%$ parasitemia microscopically (- line trace in Fig. 4a). $\mathrm{EC}_{50}$ value obtained from microscopy data was $\sim 13 \mu \mathrm{g} / \mathrm{ml}$ (Table 1 ). Two other mAbs (B1B3 and H12B8) did not show any significant decline in parasite growth.

\section{H12E1 is a strain-transcending, growth-neutralizing antibody}

For determining whether the growth inhibitory effect of H12E1 was strain specific, two different strains of $P$. falciparum were tested, namely 3D7 (chloroquine-sensitive strain) and INDO (chloroquine-resistant strain) (Fig. 4b). Both strains of $P$. falciparum showed very similar growth inhibition profiles. The estimated $\mathrm{EC}_{50}$ value for $P$. falciparum INDO was $28.5 \pm 2.7 \mu \mathrm{g} / \mathrm{ml}$. Although there are limited data on parasite strains, nonetheless, they are indicative of strain transcending nature of H12E1 induced growth inhibition.

\section{Inhibition of parasite growth in in vitro cultures is irreversible}

The nature of antibody induced growth inhibitory effect on parasite (reversible or irreversible) was investigated in in vitro cultures. Culture samples containing synchronized $P$. falciparum infected RBCs $(\sim 1 \%$ pRBCs $)$ were allowed to grow in the presence of several different concentrations of H12E1 $(0-60 \mu \mathrm{g} / \mathrm{ml})$. A replicate of the first set of cultures was also included in the experiment. After $48 \mathrm{~h}$ when a fresh cycle of merozoite invasion of RBCs had occurred, the first set of culture samples was used to determine the parasitemia. For assessing the effect of $48 \mathrm{~h}$ exposure of the parasite to H12E1 antibody on subsequent growth cycle, the antibody was removed from the second set of culture samples by washing with fresh RPMI culture medium and allowed to grow for an additional $48 \mathrm{~h}$. Thus, in this set of cultures, pRBCs had an exposure to the antibody in the first $48 \mathrm{~h}$ while the next cycle of multiplication was in a mAb free environment. Growth of the parasite in presence of several different concentrations of H12E1 at 48 and 96 h was monitored by dye fluorescence assay. Percentage parasitemia in control sample $([\mathrm{H} 12 \mathrm{E} 1]=0 \mu \mathrm{g} / \mathrm{ml})$ was also measured microscopically at all the three time points (0, 48 and 96 h). Parasite growth with time at various concentrations of the antibody is shown in Fig. 4c. In control samples (antibody free, $[\mathrm{H} 12 \mathrm{E} 1]=0 \mu \mathrm{g} / \mathrm{ml}$ ) parasitemia counts rose from the initial $(0 \mathrm{~h}) \sim 1$ to $\sim 4 \%$. In the second cycle $(96 \mathrm{~h})$ of growth, control parasitemia rose further from $\sim 4$ to $14 \%$. Control samples had $\sim 3.5$ fold more parasites at $96 \mathrm{~h}$ compared to the 48 -h count (Fig. 4c). In H12E1-treated samples at low levels of mAb $(10 \mu \mathrm{g} / \mathrm{ml})$, cultures had near normal growth $(\sim 13 \%$ parasitemia). At 20 and $30 \mu \mathrm{g} / \mathrm{ml} \mathrm{H12E1} \mathrm{(intermedi-}$ ate concentration range), $\%$ parasitemia increased to $\sim 3$ and $2 \%$, respectively, after the first cycle of growth (at $48 \mathrm{~h}$ ). These samples had $25-50 \%$ inhibition of growth as compared to control. Interestingly, in the second cycle of multiplication (after washing away the antibody), there was barely any growth in culture samples treated with $20-30 \mu \mathrm{g} / \mathrm{ml}$ of H12E1. Percentage parasitemia increased from 3 to $4 \%$ in the $20 \mu \mathrm{g} / \mathrm{ml}$ antibody-treated sample while at $30 \mu \mathrm{g} / \mathrm{ml}$ there was a decrease (from $\sim 2$ to $0.9 \%$ parasitemia at 48 and $96 \mathrm{~h}$, respectively). It was expected 

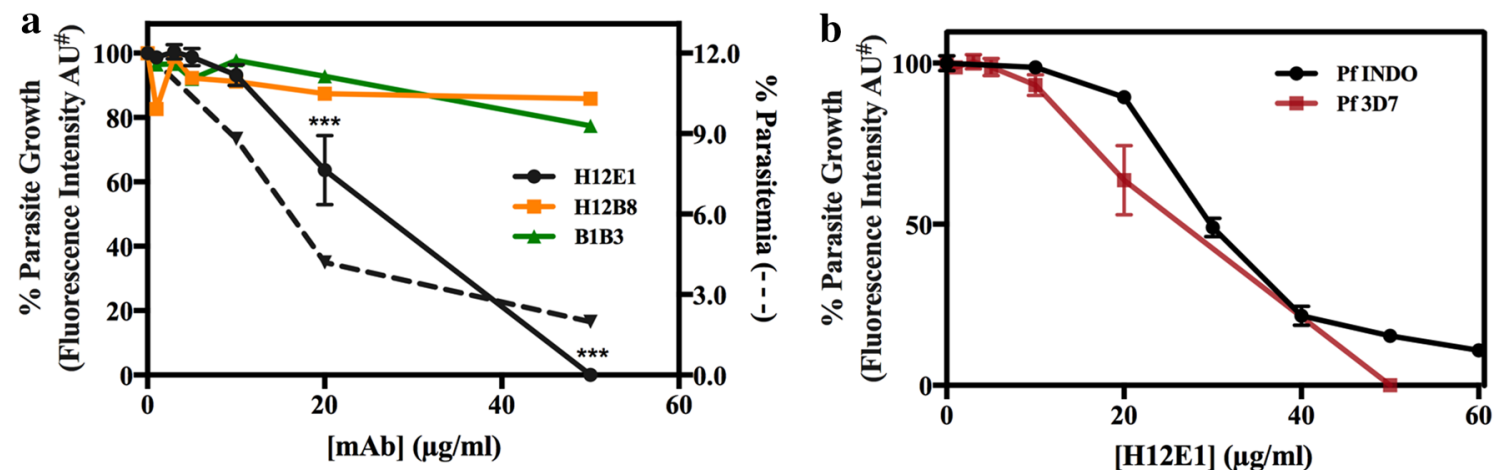

c

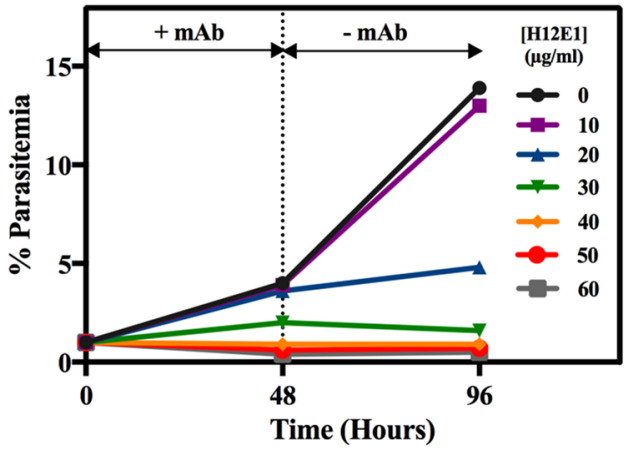

d

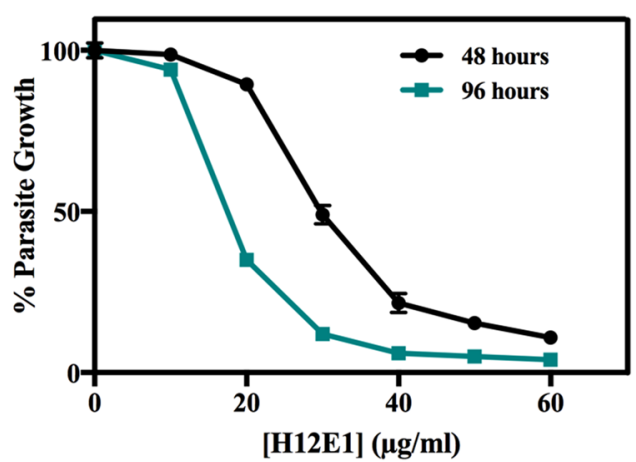

Fig. 4 Growth inhibitory activity (GIA) of various mAbs directed against rPfeno. a Effect of varying concentrations of H12E1, H12B8 and B1B3 mAbs on growth of $P$. falciparum 3D7. $\mathbf{b}$ Effect of varying concentrations of H12E1 lgG on $P$. falciparum 3D7 (chloroquine sensitive) and $P$. falciparum INDO (chloroquine resistant) strains. c Effect of exposure of the parasite cultures to H12E1 antibody on subsequent growth. Two sets of tightly synchronized ring stage parasites $(\sim 1 \%)$ were cultured in presence of varying amounts $(0-60 \mu \mathrm{g} / \mathrm{ml})$ of H12E1 lgG. At 48 h, parasitemia was measured for the first set of cultures while the second set of cultures was washed free of H12E1 antibody and supplemented with fresh medium. This was grown for another $48 \mathrm{~h}$ (in absence of $\mathrm{mAb}$ ) and \% parasitemia was determined at $96 \mathrm{~h}$. Results are presented as \% parasitemia at 0, 48 and $96 \mathrm{~h}$ for different concentrations of H12E1 and (d) \% parasitemia vs [H12E1]. Values are presented as mean \pm SD for triplicate samples. AU\#, arbitrary units; ${ }^{*}$ Marks the samples that had significant growth inhibition as compared to the control samples $\left({ }^{*} p<0.05,{ }^{* *} p<0.01,{ }^{* * *} p<0.001\right)$

that $\%$ parasitemia would rise from $\sim 3$ to $\sim 10 \%$ in samples treated with $20 \mu \mathrm{g} / \mathrm{ml}$ antibody and from 2 to $~ 7 \%$ in $30 \mu \mathrm{g} / \mathrm{ml}$ treated samples (3.5-fold increase similar to controls). The inability of the antibody exposed parasite from the first cycle to revive in the antibody free milieu in the second cycle indicates that the H12E1 antibody is 'parasiticidal' in action. Growth of the parasites in culture at various concentrations of H12E1 is shown in Fig. 4d.

Table 1 Effective concentration of mAb H12E1 for $50 \%$ growth inhibition $\left(E_{50}\right.$ ) values for Plasmodium falciparum growth in in vitro cultures

\begin{tabular}{llll}
\hline S No. & $\begin{array}{l}\text { P.falciparum } \\
\text { strain }\end{array}$ & $\mathbf{E C}_{\mathbf{5 0}}(\boldsymbol{\mu g} \mathbf{/ m l})$ & Method \\
\hline 1 & $3 \mathrm{D} 7$ & 13.0 & Microscopy data Fig. 4a \\
2 & $3 \mathrm{D} 7$ & $21.3 \pm 2.1$ & SYBR dye data Fig. 4a \\
3 & INDO & $28.5 \pm 2.9$ & SYBR dye data Fig. 4b \\
5 & $3 \mathrm{D} 7$ & $28.5 \pm 2.7$ & 48 h data Fig. 4d \\
6 & $3 \mathrm{D} 7$ & $16.6 \pm 1.3$ & 96 h data Fig. 4d \\
\hline
\end{tabular}

The $\mathrm{EC}_{50}$ values obtained from these titrations were $28.5 \pm 2.7$ (from $48 \mathrm{~h}$ data) and $16.6 \pm 1.3 \mu \mathrm{g} / \mathrm{ml}$ (96 h data), respectively (Table 1 ). $\mathrm{EC}_{50}$ values estimated by different methods of parasitemia measurements (dye assay and microscopy) for two strains of $P$. falciparum ranged between 13.0 and $28.5 \mu \mathrm{g} / \mathrm{ml}$ (Table 1 ).

\section{Passive immunization of mice with $\mathrm{H} 12 \mathrm{E} 1 \mathrm{mAb}$ protects against heterologous parasite challenge in vivo}

Passive immunization experiments were performed in mice to assess the in vivo growth neutralizing ability of H12E1. In two different experiments, mice were challenged with $P$. yoelii $17 \mathrm{XL}$ or $P$. berghei strain ANKA and injected with purified IgG on the same day. The protective effect of H12E1 was assessed by measuring the effect of injected antibody on the parasitemia and comparing that with the pre-immune IgGs injected controls. Results obtained for two different species of mouse malarial parasites are shown in Fig. 5. In P. yoelii challenged group, passive infusion of H12E1 clearly attenuated parasitemia in experimental 

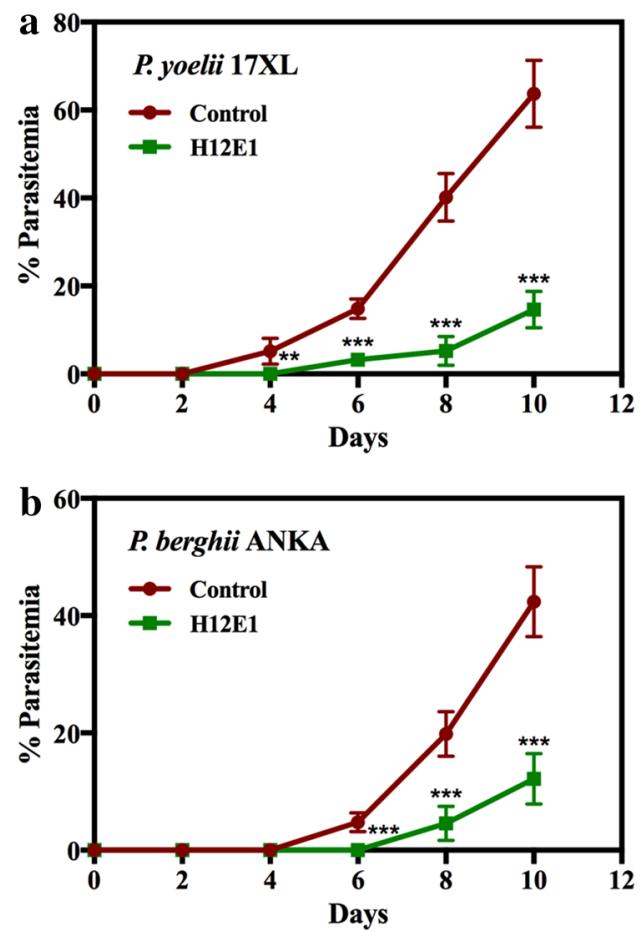

Fig. 5 Effect of passive immunization with $\mathrm{H} 12 \mathrm{E} 1 \mathrm{mAb}$ on parasitemia in Plasmodium yoelii 17XL (or Plasmodium berghei ANKA) infected mice. a Mice $(n=5)$ were administered with $0.75 \mathrm{mg} / 100 \mu \mathrm{l}$ H12E1 (experimental) or pre-immune lgGs intravenously. All mice were challenged with $\sim 1 \times 10^{5}$ P. yoelii $17 \mathrm{XL}$ pRBCs. Mean $\%$ parasitemia for the two groups of animals is shown with post challenge days. $\mathbf{b}$ Two groups of mice ( $n=5$ animals) were administered with $1 \mathrm{mg} / 100 \mu \mathrm{l} \mathrm{H12E} 1$ (experimental) or pre-immune IgGs (control). All mice were challenged with $\sim 10^{5}$ P. berghei ANKA pRBCs. Passive transfer of H12E1 in infected mice resulted in significant reduction in rise of parasitemia in experimental group as compared to control group $\left({ }^{* *} p<0.01 ;{ }^{* * *} p<0.001\right)$

animals compared to the controls (Fig. 5a). The rise in parasitemia was delayed and remained low $(\sim 15 \%)$ in H12E1 injected mice for the first 10 days, while the parasitemia in the control mice shot up to $\geq 60 \%$.

Similar results were obtained in the experiment where P. berghei strain ANKA was used as the infective agent (Fig. 5b). In this case also \% parasitemia rose rapidly in controls reaching to $>50 \%$ by 10 th day while in the experimental group, it was curtailed to $<15 \%$. Statistical comparison of the experimental group with the control showed significant reduction in \% parasitemia. For the duration that mAb remained in the system, parasitemia too remained under control. These experiments provided an effective way to test the in vivo protective potential of the antibody for parasite neutralization as have been done earlier $[17,41]$.
Kinetic and thermodynamic measurements on interaction of rPfeno with mAb H12E1

Binding affinity and half-life of an antibody-antigen complex are important determinants of an antibody's potency to neutralize a pathogen [42, 43]. Direct interaction of H12E1 with rPfeno was monitored using Surface Plasmon Resonance (SPR). Binding sensograms obtained for H12E1 interaction with rPfeno are shown in Fig. 6a. These sensograms were analyzed by fitting the data to a 1:1 binding site model. The association rate constant for antibody-antigen interaction $k_{a}=6.5 \times 10^{5} / \mathrm{M} / \mathrm{S}$. The best-fit value obtained by fitting each of the dissociation traces in the sensogram gave the dissociation rate constant $k_{d}=4.95 \times 10^{-3} / \mathrm{S}$ (Fig. 6b). The ratio of the two rate constants $\left(k_{d} / k_{a}\right)$ yielded a dissociation constant $\mathrm{K}_{\mathrm{D}}=7.58 \times 10^{-9} \mathrm{M}$. Considering the $\mathrm{K}_{\mathrm{D}}$ value obtained here, it can be argued that at a mAb concentration of $\sim 1-2 \mu \mathrm{g} / \mathrm{ml}, \sim 50 \%$ of the antigen would be in bound state. The value of the association rate constant obtained here falls well within the range suggested earlier $\left(1 \times 10^{5} / \mathrm{M} / \mathrm{S}\right)$ [44]. A similar value was reported for PfRH5 $\left(\sim 2 \times 10^{6} / \mathrm{M} / \mathrm{S}\right)$ [43] for the kinetics of merozoite neutralization by antibodies. Using the dissociation rate constant $\left(k_{d}\right)$ for mAb-rPfeno complex, the half-life $\left(\mathrm{t}_{1 / 2}=\ln [0.5] / 60 * k_{d}\right)$ of rPfeno-H12E1 complex was also computed $\left(t_{1 / 2}=10.5 \mathrm{~min}\right)$. Since merozoites reinvade fresh erythrocytes in a couple of minutes of their egress, it requires high concentrations of high specificity antibodies that can bind rapidly (high $k_{a}$ ) and stably (long $t_{1 / 2}$ ) so as to have a substantial fraction of merozoites saturated with antibody to generate the inhibitory effect [44, 45]. The values obtained here for H12E1 interaction are well within the range assuming that the cell surface enolase has a binding behavior with H12E1 similar to free Pfeno in solution.

\section{Binding of EWGWS specific mAb to rPfeno did not affect enzyme activity}

Enolase is a glycolytic enzyme that catalyzes the inter conversion of 2-phosphoglycerate and phosphoenolpyruvate. As Plasmodium has a single gene for enolase, inhibition of this activity could result in parasite growth inhibition. To determine whether the binding of H12E1 antibody had any effect on the enzyme activity, rPfeno ( 80 nmoles) was incubated with different amounts of $\mathrm{mAb}(0,80$ and 160 nMoles) and the activity of rPfeno-mAb complex was measured. The activity measurements showed that the binding of enolase to H12E1 had no effect on its catalytic activity (Fig. 7a) indicating that the antibody-binding motif in enolase is likely to be exclusive of the active site of the protein. The relative location of various functional domains in the molecule were examined using molecular 


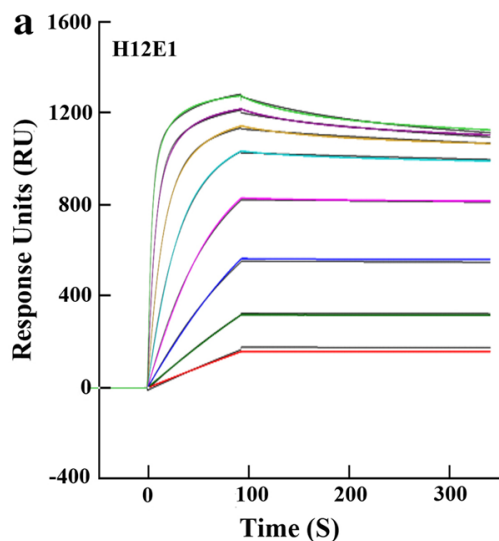

\begin{tabular}{|c|c|c|c|c|c|c|c|c|}
\hline $\mathbf{m A b}$ & Experiment & $\begin{array}{c}k_{a} \\
\left(\mathbf{M}^{-1} \mathbf{S}^{-1}\right)^{5}\end{array}$ & $\begin{array}{c}\boldsymbol{k}_{d} \\
\left(\mathbf{S}^{-1}\right)^{\prime}\end{array}$ & $\begin{array}{l}\mathbf{K}_{\mathrm{p}} \\
(\mathbf{M})\end{array}$ & $\underset{(\mu \mathrm{g} / \mathbf{m l})}{\mathbf{K}_{\mathrm{D}}}$ & $\begin{array}{c}\text { mAb-Ag } \\
\text { Complex } \\
\text { Half Life } \\
\text { (min) }\end{array}$ & $\begin{array}{l}\text { R-max } \\
\text { (RU) }\end{array}$ & $\begin{array}{l}\mathbf{C h i}^{2} \\
\left(\mathbf{R U}^{2}\right)\end{array}$ \\
\hline \multirow{3}{*}{ H12E1 } & 1 & $6.48 \mathrm{E} 5$ & $4.95 \mathrm{E}-3$ & $7.63 \mathrm{E}-9$ & 1.14 & 10.64 & 2682 & 85 \\
\hline & 2 & $6.56 \mathrm{E} 5$ & $4.94 \mathrm{E}-3$ & $7.53 \mathrm{E}-9$ & 1.12 & 10.52 & 2680 & 88 \\
\hline & Median & $\begin{array}{l}6.52 \mathrm{E} 5 \\
+5.1 \mathrm{E} 2\end{array}$ & $\begin{array}{r}4.95 \mathrm{E}-3 \\
\pm 5.6 \mathrm{E}-5\end{array}$ & $\begin{array}{c}7.58 \mathrm{E}-9 \\
\pm 0.05 \mathrm{E}-9\end{array}$ & $1.13 \pm 0.01$ & $10.58 \pm 0.06$ & 2681 & 86.5 \\
\hline
\end{tabular}

"SE is given for median values

Fig. 6 Determination of association-dissociation rate constants for interaction between rPfeno and mAb H12E1. Thermodynamic and kinetic parameters for rPfeno-H12E1 interaction were measured using Surface Plasmon Resonance. a Sensogram shown represents 1:1 binding of bivalent $\mathrm{mAb}$ with dimeric enolase. Measurements were made in duplicates with different traces representing various concentrations of $\mathrm{mAb}(0.78-100 \mathrm{nM})$ used with fixed concentration of rPfeno on the CM5 chip. $\mathbf{b}$ Best fit kinetic parameters were derived from the sensogram. Dissociation constant $K_{D}$ was computed from association and dissociation rate constants. The half-life of mAb-Antigen complex was computed using $\mathrm{t}_{1 / 2}=\left(\ln [0.5] / 60^{*} k_{d}\right)$. Goodness of fit as judged by $\mathrm{Chi}^{2}$ was $<10 \%$ of $\mathrm{R}_{\max }$

modelling and visualisation tools. For this, a 3D-structure of Pfeno was modelled based on Toxoplasma gondii enolase 1(TgEno1) (PDB: 3OTR). Structural mapping of the four functional sites: (i) the plasminogen binding site ${ }^{277}$ DKSLVK $^{282}$ (blue) [19]; (ii) the active site (residues - Glu175, Glu218, Asp253, Glu304, Asp331, Lys356, Arg385, Lys407 and His384) (red) [22]; (iii) the subunit-subunit interface region (residues-His198, Tyr59, Glu23, Arg416, Arg11 and Glu427) [46] (green); and, (iv) the EWGWS epitope (pink) (target for the growth inhibitory antibodies) showed them all to be non-overlapping (Fig. 7b). This was in line with the above observation that the binding of H12E1 to Pfeno did not affect the catalytic activity. Thus, the possibility of inhibition of glycolysis being the cause of antibody induced growth inhibition was excluded. Evidence presented here supports the conclusion that the potent growth inhibition arose solely due to the blockade of the merozoite surface enolase. The first three sites (i to iii) are conserved across all enolases and blockade of anyone of them in Pfeno will also block host enolases resulting in adverse physiological effects in the host system. Since EWGWS is present only in the parasite (apicomplexans) enolases, targeting this region could yield parasite specific growth inhibitory effects.

\section{Discussion}

Enolase is a glycolytic enzyme with a highly conserved structure and multiple moonlighting functions [47, 48]. Several pathogens have enolase expressed on their cell surface where it assists in host tissue invasion [49-54]. In Plasmodium, enolase localizes in multiple organelles (diverse sub-cellular localization) where it is likely to participate in different physiological functions [18]. Presence of Pfeno on the surface of sporozoites, merozoites and ookinetes raised the possibility of its involvement in host cell invasion. Recently, anti-Pfeno antibodies have been shown to inhibit growth at erythrocytic and mosquito stages presumably by blocking the invasion by merozoites and ookinetes [19, 20, 23, 50]. Antibody induced inhibition of ookinete was mediated through the plasminogen receptor function of Pfeno, $[19,50]$ while the merozoite inhibition appeared to be mediated by blocking a unique epitope, EWGWS [23, 24]. Data presented here further validated that EWGWS is the target for the merozoite neutralizing antibodies. The inhibitory antibodies exert their effect on ookinete by blocking the binding of plasminogen to ${ }^{277} \mathrm{DKSLVK}^{282}$ domain of Pfeno, while merozoite inhibitory antibody (H12E1) functions through the ${ }^{104}$ EWGWS ${ }^{108}$ epitope. The underlying molecular mechanisms in the two cases are likely to be quite different. In ookinetes, Pfeno functions as a receptor for plasminogen as well as a ligand for mosquito mid-gut epithelial cell receptor [19], whereas in merozoites, it is the EWGWS epitope of Pfeno that serves as a ligand for some yet to be identified receptor on human erythrocyte surface. The effect of anti-Pfeno antibodies on sporozoite invasion of hepatocytes has not yet been examined. It will be interesting to see whether anti-Pfeno antibodies can disrupt sporozoite invasion of hepatocytes.

The observed inhibition of growth shown by H12E1 $\mathrm{mAb}$ was $\geq 90 \%$ at $<100 \mu \mathrm{g} / \mathrm{ml}$. There are very few reports where such potent inhibition of merozoite invasion in in vitro cultures has been reported. Some of the 


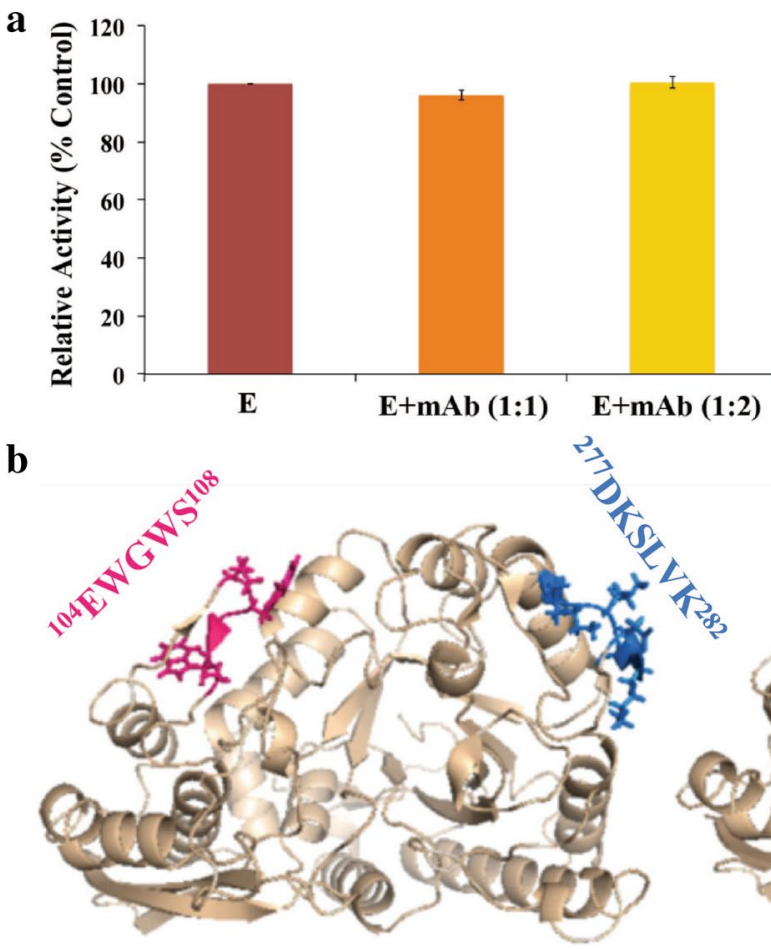

(i)

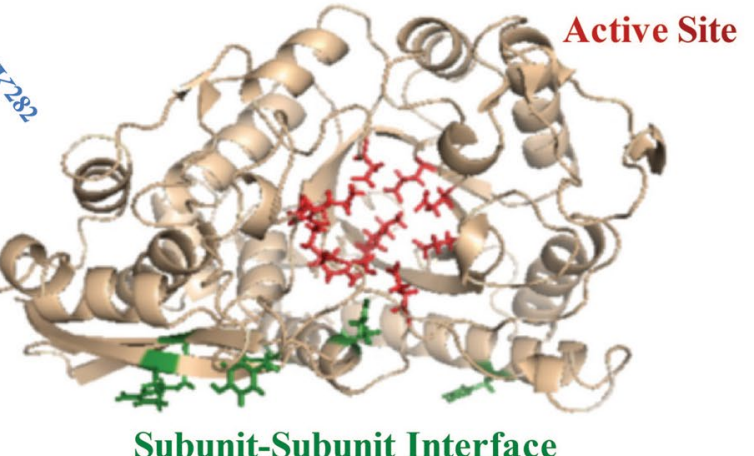

(ii)

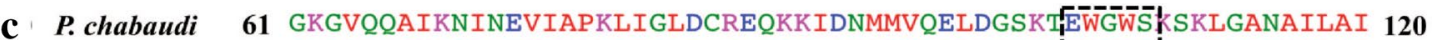 P. berghei 61 GKGVQQAIKNINEIIAPKLIGLDCREQKKIDNMMVQELDGSKTEWGWSKSKLGANAILAI 120 P. yoelii 59 GKGVQOAIKNINEIIAPKLIGLDCREOKKIDNMMVOELDGSKTIEWGWSKSKLGANAILAI 118 P. falciparum 61 GKGVOKAIKNINEIIAPKLIGMNCTEOKKIDNLMVEELDGSKNEWGWSKSKLGANAILAI 120 P. vivax 61 GKGVQKAIKNINEHIAPKLIGLDCREQKKIDNMMVEELDGSKNEWGWSKSKLGANAILAI 120 P. knowlesi 61 GKGVQKAINNINEHIAPKLIGMDCREQKKIDNLMVEELDGSKNEWGWSKSKKLGANAILAI 120 $* * * * *: * *: * * * * * * * * * * *:: * * * * * * * *: * *: * * * * * * * * * * * * * * * * * * * * * * *$

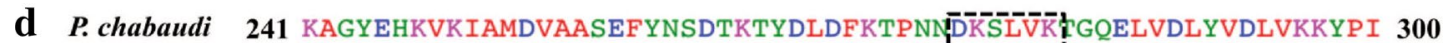
P. berghei 241 KAGYENKVKIAMDVAASEFYNIETKTYDLDFKTPNNDKSLVKGGELVDLYIELVKKYPI $\mathbf{3 0 0}$ P. yoelii 239 KAGYENKVKIAMDVAASEFYNSETKTYDLDFKTPNNDKSLVK TGELVDLYIELVKKYPI 298 P. falciparum 241 SAGYEGKVKIAMDVAASEFYNSENKTYDLDFKTPNNDKLLVKGAQLVDLYIDLVKKYPI 300 P. vivax 241 SAGYEGKVKIAMDVAASEFYQADTKTYDLDFKTPNA DKLVKKGAELVNLYIDMVKKYPI 300 P. knowlesi 241 SAGYEGKVIAMDVAASEFYQADSKTYDLDFTPNDESMVK DGAELVNLYIDMVKKYPI 300 . $* * * * * * * * * * * * * * * * *::: * * * * * * * * * * * * * * *: * *: *:: * *: * *::: * * * * * *$

Fig. 7 a Effect of mAb (H12E1) binding on the enzyme activity of rPfeno. Activity of enolase was assayed using $80 \mathrm{nmoles}(2 \mu \mathrm{g})$ of rPfeno. For the measurement of antibody effect on enzyme activity, different amounts (80 and 160 nmoles) of H12E1 were mixed with rPfeno (80 nmoles) and incubated for 30 min before using for enolase activity assays. b 3D-structure of Pfeno was modelled using Toxoplasma gondii enolase 1 crystal structure as template (TgENO1; PDB: 3OTR). Residues that constitute the different functional regions are highlighted in different colours: plasminogen binding site (blue); active site residues (red); subunit-subunit interface (green); and, EWGWS (pink)—-target epitope for growth neutralizing antibody. Note the non-overlapping nature of all four regions. $\mathbf{c}, \mathbf{d}$ Homology comparison of enolase sequence in the vicinity of EWGWS and DKSLVK (plasminogen binding site) in various species of Plasmodium. Note the conserved sequence and their location in the protein

mAbs raised against $P$. falciparum reticulocyte binding protein homolog 5 (PfRH5) had shown similar inhibition [55]. H12E1 antibody was quite effective against multiple species of Plasmodium (P. yoelii, P. berghei and P. falciparum) and different strains of $P$. falciparum (3D7 and INDO). Given the highly conserved nature of the target sequence and its location in the polypeptide (Fig. 7c), it is not surprising that the antibody has species and strain transcending parasite neutralization activity. The ability of this antibody to block erythrocyte invasion with high efficiency and inhibit growth in heterologous species and strains other than P. falciparum 3D7 makes it a promising candidate for a blood stage anti malaria vaccine. One of the major limitations of this epitope is the poor 
immunogenicity of EWGWS. As all plant enolases have this epitope [22, 56], humans (or other vertebrate hosts) get exposed to this antigen early on in their life (through food). There have been suggestions that oral tolerance to food antigens could induce systemic suppression [57]. Such suppression could be one of the factors responsible for poor immunogenicity of EWGWS. Observation of partial protection in EWGWS immunized mice was largely due to low titers of induced antibodies [23]. Thus, for greater efficacy in protection against malaria, this epitope will need to be presented in a highly immunogenic context, employing novel methods of antigen presentation [55, 58-61].

Several antigens derived from the three stages of parasite life cycle (i.e. pre-erythrocytic, erythrocytic and mosquito stages) have been tested for their ability to protect against malaria and block its transmission $[8,9,62]$. Some of the erythrocytic stage antigens, mostly of merozoite origin, have undergone phase I/II level trials [12]. Apical membrane antigen 1 (AMA-1) that is expressed by both sporozoites and merozoites plays a key role in invasion of hepatocytes and erythrocytes, showed strain specific reduction in malaria cases, but offered no clinical protection $[13,63,64]$. Other vaccine candidates such as Merozoite Surface Protein 1 (MSP 1), Erythrocyte Binding Antigen Region II (EBA 175) etc. have also undergone Phase I and Phase II level trials [65-67]. In all these efforts, the antibody response failed to cover antigenic polymorphism and yielded only low efficacy allele specific protective response [12]. Multi-stage vaccines containing candidate antigens from multiple stages have also been tested $[68,69]$. Extensive efforts to cover all genetic variations in field strains have not succeeded mostly due to the failure to overcome the issue of polymorphism. Stage specific expression, high degree of polymorphism and requirement for very high titers of induced antibodies has hindered any meaningful outcome from these efforts. Recently, PfRH5 has emerged as a leading antigen for erythrocytic stage vaccine [70]. PfRH5 is a merozoite adhesin essential for erythrocyte invasion and is susceptible to vaccine inducible strain transcending parasite neutralizing antibodies [71-73]. PfRH5 has critical non-redundant function during merozoite invasion of erythrocytes [74] and does not appear to be a target of antibodies acquired in natural immunity [72]. Results from a recent Phase Ia trial have been very promising [75]. There are some interesting parallels between Pfeno and PfRH5. Both antigens have a high degree of sequence conservation (none or low genetic polymorphism) [73, 76-78], both are targets for strain transcending parasite neutralizing antibodies, mAbs directed towards certain specific epitopes in these proteins have shown strong growth inhibition [55] and both appear to be under low level natural immune pressure. However, an added advantage with Pfeno is that it has cell surface expression at all the three invasive stages [18], two (merozoites and ookinetes) of which are known targets of parasite neutralizing antibodies $[19,20,23]$. Thus, it could be developed into a 'two stage' (erythrocytic and transmission blocking) vaccine candidate. The possibility of anti-Pfeno antibodies targeting sporozoites should also be explored.

For the development of a multivalent vaccine that is effective against multiple species and strains of the parasite, with an ability to neutralize growth at multiple stages, one will need to combine several antigens [15, 17, 62]. Epitope based approaches for each target antigens are also anticipated in near future. Hence, antigens like Pfeno with identified protective epitopes, ability to neutralize multiple species/strains and with potential to target multiple stages in parasite life cycle could be the promise of future.

\section{Conclusions}

In this paper, we have described the generation of a monoclonal antibody H12E1 that has a potent merozoite neutralizing activity and targets the EWGWS epitope in Pfeno. The mAb induced an almost complete inhibition of parasite growth in in vitro cultures of the asexual stages $(>90 \%$ inhibition at $<100 \mu \mathrm{g} / \mathrm{ml})$. Active immunization of mice with an antigenic peptide containing EWGWS epitope is known to confer partial protection [23]. Passive immunization of infected mice with H12E1 (anti-EWGWS antibody) led to drastic reduction in parasitemia, indicating EWGWS to be a valid target for parasite neutralizing antibodies. Limited data provided on growth inhibitory activity of the antibody on two different strains of $P$. falciparum (3D7 and INDO) and three different species of Plasmodium (P. falciparum, P. yoelii and $P$. berghei) indicates the species and strain transcending nature of this epitope. Plasmodium spp. enolase has thus emerged as a unique antigen that has surface expression at all three invasive stages; is an invasion target in at least two stages (merozoites and ookinetes); the target epitope of which is highly conserved, is monomorphic and has the ability to induce protective antibodies on immunization. Poor immunogenicity of this epitope is a concern that needs to be addressed. Thus, antigenic epitope EWGWS from Pfeno could be a good candidate for the development of a two-stage malaria vaccine. 


\section{Additional files}

Additional file 1. Purification, specificity and isotyping of mAbs. Three mAbs that had high reactivity with WT-ePfeno were purified. (A) Coomassie stained 10\% SDS-PAGE for the Protein-A Sepharose purified lgGs from hybridoma supernatants of the three mAbs. Two bands corresponding to heavy and light chain of antibody are observed. (B) Western blot of purified rPfeno with each $\mathrm{mAb}$ and $(\mathrm{C})$ isotyping of $\mathrm{mAbs}$. All three mAbs were of $\lg \mathrm{g} 2 \mathrm{~b}$ class of immunoglobulins.

Additional file 2. Quantitation of un-ruptured schizonts in anti-rPfeno antibody treated cultures at $48 \mathrm{~h}$ post antibody addition. Control samples had no schizonts. Data are expressed as percent of total Schizonts present at $24 \mathrm{~h}$ post antibody addition (see Fig. 3).

\section{Abbreviations}

ABTS: 2,2'-azino-bis[3-ethylbenzothiazoline-6-sulfonic acid]-diammonium salt; Ab: antibody; Ag: antigen; CQ: chloroquine; pRBCs: parasitized red blood cells; EDC: $N$-(3-dimethylaminopropyl)- $N^{\prime}$-ethylcarbodiimide hydrochloride; GIA: growth inhibitory activity; h: hours; mAb: monoclonal antibody; NHS: N-hydroxysuccinimide; PBS: phosphate buffer saline; Pfeno: Plasmodium falciparum enolase; SPR: Surface Plasmon Resonance; $\Delta^{5}$-rPfeno: pentapeptide deletion variant of rPfeno; S108G-rPfeno: S108G variant of rPfeno; Rec-NP: recombinant nanoparticles; WT-rPfeno: wild type recombinant Plasmodium falciparum enolase; WT-NP: wild type nanoparticles; Yeno: yeast enolase.

\section{Authors' contributions}

GKJ: conceived the project and designed the study, planned laboratory work, data analysis, writing and editing of the manuscript: DS: study design, planned laboratory work, data analysis and editing; SD: planned experiments, mAb screening, IgG purification, mAb specificity, nanoparticle experiment, GIAs, data analysis, figure preparations; AT: mAb screening; CB: IgG purification, passive immunization, coordinating collaboration, statistical analysis; MR and PA: mAb concentration dependence of Gl, GIA strain effects; RV: ELISA, SPR measurements, analysis; AM: Molecular modelling, ELISA measurements with variants, statistical analysis, figure preparations, manuscript editing. All authors read and approved the final manuscript.

\section{Authors' information}

GKJ is a Professor at TIFR. His research interests include structure-function relationship in protein molecules, NMR and optical spectroscopy and their application to structure, identification of drug targets and vaccine candidates.

DS is Group Leader, Malaria Drug Discovery Group at ICGEB, New Delhi. His research interests include designing structure and function into peptides, antimicrobial peptides, activity guided chromatographic isolation of secondary metabolites and synthetic organisms.

SD and AM were Masters students in GKJ lab. SD is currently at Harvard University pursuing her Ph.D. USA.

AT was a graduate from Brown University currently pursuing Ph.D. at MIT, Delhi.

MR and PA are research scholars pursuing Ph.D. in DS lab at ICGEB, New

RV is a Post Doctoral Fellow in GKJ lab at TIFR.

CB is a Scientific Officer in GKJ lab at TIFR.

\section{Author details}

1 Department of Biological Sciences, Tata Institute of Fundamental Research, Homi Bhabha Road, Colaba, Mumbai, India. ${ }^{2}$ International Center for Genetic Engineering and Biotechnology, Aruna Asif Ali Marg, New Delhi, India. ${ }^{3}$ Present Address: Department of Genetics and Complex Diseases, Harvard T. H. Chan School of Public Health, Graduate School of Arts and Sciences, Harvard University, Boston, USA. ${ }^{4}$ Present Address: Department of Biology, Whitehead Institute for Biomedical Research, Massachusetts Institute of Technology (MIT), Boston, USA.

\section{Acknowledgements}

We thank Prof. Deepak Mathur and Dr. Jayshree Dharmadhikari for allowing us to use their microscope. Thanks are also due to Dr. Sheetal Suryavanshi for performing tail vein injections in mice.

\section{Competing interests}

The authors declare that they have no competing interests.

\section{Availability of data and materials}

All data generated or analyzed during this study are included in this published article and its additional files.

\section{Consent for publication}

Not applicable.

\section{Ethics approval and consent to participate}

Prior approval for the animal experiments involving mice was obtained from the Institutional Animal Ethics Committee (IAEC) of the Tata Institute of Fundamental Research (Project Approval No.: TIFR/IAEC/2013-2 and TIFR/IAEC/20161). TIFR animal facility is registered with the 'Committee for the Purpose of Control and Supervision of Experiments on Animals', Ministry of Environment, Forest and Climate Change, Government of India with registration number 56/ GO/ReBi/S/99/CPCSEA and follows their guidelines/regulations. Approval for collection of human blood samples was obtained from the Institutional Ethics Committee of TIFR. Institute ethics committee also approved the use of TIFR pathology lab (a Government of India funded facility) for blood sample collection. Written consent from volunteers for the proposed purpose for which the donated blood will be used was taken.

\section{Funding}

Research was funded by a grant from Department of Atomic Energy, Government of India to GKJ through Tata Institute of Fundamental Research, Mumbai, India. DS received intra-mural funding from ICGEB, New Delhi.

\section{Publisher's Note}

Springer Nature remains neutral with regard to jurisdictional claims in published maps and institutional affiliations.

Received: 2 May 2018 Accepted: 13 August 2018

Published online: 20 August 2018

\section{References}

1. WHO. World malaria report 2017. Geneva: World Health Organization; 2017. http://www.joint/malaria/publications/world-malaria-report-2017/ en/ Accessed 10 Apr 2018.

2. Kaslow DC, Biernaux S. RTS, S: toward a first landmark on the Malaria Vaccine Technology Roadmap. Vaccine. 2015;33:7425-32.

3. Foquet L, Hermsen CC, van Gemert GJ, Van Braeckel E, Weening KE, Sauerwein $\mathrm{R}$, et al. Vaccine-induced monoclonal antibodies targeting circumsporozoite protein prevent Plasmodium falciparum infection. J Clin Invest. 2014;124:140-4

4. RTS, S Clinical Trials Partnership, Agnandji ST, Lell B, Fernandes JF, Abossolo BP, Methogo BG, et al. A phase 3 trial of RTS, S/AS01 malaria vaccine in African infants. N Engl J Med. 2012;367:2284-95.

5. Mahmoudi S, Keshavarz H. Efficacy of phase 3 trial of RTS, S/AS01 malaria vaccine: the need for an alternative development plan. Hum Vaccin Immunother. 2017;13:2098-101.

6. RTS,S Clinical Trials Partnership. Efficacy and safety of RTS,S/AS01 malaria vaccine with or without a booster dose in infants and children in Africa: final results of a phase 3 , individually randomised, controlled trial. Lancet. 2015:386:31-45.

7. Matuschewski K. Vaccines against malaria-still a long way to go. FEBS J. 2017:284:2560-8.

8. Nega D, Alemu A, Tasew G. Malaria vaccine development: recent advances alongside the barriers. J Bacteriol Parasitol. 2016;7:300.

9. Schwartz L, Brown GV, Genton B, Moorthy VS. A review of malaria vaccine clinical projects based on the WHO rainbow table. Malar J. 2012;11:11.

10. Tran TM, Portugal S, Draper SJ, Crompton PD. Malaria vaccines: moving forward after encouraging first steps. Curr Trop Med Rep. 2015;2:1-3.

11. Goodman AL, Draper SJ. Blood-stage malaria vaccines-recent progress and future challenges. Ann Trop Med Parasitol. 2010;104:189-211.

12. Miura K. Progress and prospects for blood-stage malaria vaccines. Expert Rev Vaccines. 2016:15:765-81. 
13. Thera MA, Doumbo OK, Coulibaly D, Laurens MB, Ouattara A, Kone AK, et al. A field trial to assess a blood-stage malaria vaccine. N Engl J Med. 2011;365:1004-13.

14. Wright GJ, Rayner JC. Plasmodium falciparum erythrocyte invasion: com bining function with immune evasion. PLoS Pathog. 2014;10:e1003943.

15. Pandey AK, Reddy KS, Sahar T, Gupta S, Singh H, Reddy EJ, et al. Identification of a potent combination of key Plasmodium falciparum merozoite antigens that elicit strain-transcending parasite-neutralizing antibodies. Infect Immun. 2013;81:441-51.

16. Williams AR, Douglas AD, Miura K, Illingworth JJ, Choudhary P, Murungi LM, et al. Enhancing blockade of Plasmodium falciparum erythrocyte invasion: assessing combinations of antibodies against PfRH5 and other merozoite antigens. PLoS Pathog. 2012;8:e1002991.

17. Narum DL, Ogun SA, Batchelor AH, Holder AA. Passive immunization with a multicomponent vaccine against conserved domains of apical membrane antigen 1 and 235-kilodalton rhoptry proteins protects mice against Plasmodium yoelii blood-stage challenge infection. Infect Immun. 2006;74:5529-36.

18. Bhowmick IP, Kumar N, Sharma S, Coppens I, Jarori GK. Plasmodium falciparum enolase: stage-specific expression and sub-cellular localization. Malar J. 2009;8:179.

19. Ghosh AK, Coppens I, Gardsvoll H, Ploug M, Jacobs-Lorena M. Plasmodium ookinetes coopt mammalian plasminogen to invade the mosquito midgut. Proc Natl Acad Sci USA. 2011:108:17153-8.

20. Pal-Bhowmick I, Mehta M, Coppens I, Sharma S, Jarori GK. Protective properties and surface localization of Plasmodium falciparum enolase. Infect Immun. 2007:75:5500-8.

21. Pal-Bhowmick I, Sadagopan K, Vora HK, Sehgal A, Sharma S, Jarori GK. Cloning, over-expression, purification and characterization of Plasmodium falciparum enolase. Eur J Biochem. 2004;271:4845-54.

22. Read M, Hicks KE, Sims PF, Hyde JE. Molecular characterisation of the enolase gene from the human malaria parasite Plasmodium falciparum. Evidence for ancestry within a photosynthetic lineage. Eur J Biochem. 1994;220:513-20.

23. Dutta S, DasSarma P, DasSarma S, Jarori GK. Immunogenicity and protective potential of a Plasmodium spp. enolase peptide displayed on archaeal gas vesicle nanoparticles. Malar J. 2015;14:406

24. Vora HK, Shaik FR, Pal-Bhowmick I, Mout R, Jarori GK. Effect of deletion of a plant like pentapeptide insert on kinetic, structural and immunological properties of enolase from Plasmodium falciparum. Arch Biochem Biophys. 2009;485:128-38.

25. Page M, Thorpe R. Purification of IgG by Precipitation with Sodium Sulfate or Ammonium Sulfate. In: Walker JM, editor. The Protein Protocols Handbook. 2nd ed. Totowa: Humana Press; 2009. p. 983-4.

26. Laemmli UK. Cleavage of structural proteins during the assembly of the head of bacteriophage T4. Nature. 1970;227:680-5.

27. Goswami A, Singh S, Redkar VD, Sharma S. Characterization of PO, a ribosomal phosphoprotein of Plasmodium falciparum. Antibody against amino-terminal domain inhibits parasite growth. J Biol Chem. 1997;272:12138-43

28. Lambros C, Vanderberg JP. Synchronization of Plasmodium falciparum erythrocytic stages in culture. J Parasitol. 1979;65:418-20.

29. Singh NJ, Sehgal A, Sharma S. Characterization of a differential immunoscreen epitope of Plasmodium falciparum using combinatorial agents. Parasite Immunol. 2000;22:333-40.

30. Chatterjee S, Singh S, Sohoni R, Kattige V, Deshpande C, Chiplunkar $\mathrm{S}$, et al. Characterization of domains of the phosphoriboprotein P0 of Plasmodium falciparum. Mol Biochem Parasitol. 2000;107:143-54.

31. Rajeshwari K, Patel K, Nambeesan S, Mehta M, Sehgal A, Chakraborty T, et al. The $\mathrm{P}$ domain of the $\mathrm{PO}$ protein of Plasmodium falciparum protects against challenge with malaria parasites. Infect Immun. 2004;72:5515-21.

32. Lema OE, Carter JY, Nagelkerke N, Wangai MW, Kitenge P, Gikunda SM, et al. Comparison of five methods of malaria detection in the outpatient setting. Am J Trop Med Hyg. 1999;60:177-82.

33. Trager $W$, Jensen JB. Human malaria parasites in continuous culture. Science. 1976:193:673-5.

34. Smilkstein M, Sriwilaijaroen N, Kelly JX, Wilairat P, Riscoe M. Simple and inexpensive fluorescence-based technique for high-throughput antimalarial drug screening. Antimicrob Agents Chemother. 2004;48:1803-6.
35. Bennett TN, Paguio M, Gligorijevic B, Seudieu C, Kosar AD, Davidson E, et al. Novel, rapid, and inexpensive cell-based quantification of antimalarial drug efficacy. Antimicrob Agents Chemother. 2004;48:1807-10.

36. Ma C, Harrison P, Wang L, Coppel RL. Automated estimation of parasitaemia of Plasmodium yoelii-infected mice by digital image analysis of Giemsa-stained thin blood smears. Malar J. 2010;9:348.

37. Ruan J, Mouveaux T, Light SH, Minasov G, Anderson WF, Tomavo S, et al. The structure of bradyzoite-specific enolase from Toxoplasma gondii reveals insights into its dual cytoplasmic and nuclear functions. Acta Crystallogr D Biol Crystallogr. 2015;71:417-26.

38. Lill MA, Danielson ML. Computer-aided drug design platform using PyMOL. J Comput Aided Mol Des. 2011;25:13-9.

39. Dutta S, Moitra A, Mukherjee D, Jarori GK. Functions of tryptophan residues in EWGWS insert of Plasmodium falciparum enolase. FEBS Open Bio. 2017;7:892-904.

40. Dutta S, Mukherjee D, Jarori GK. Replacement of Ser108 in Plasmodium falciparum enolase results in weak $\mathrm{Mg}(\mathrm{II})$ binding: role of a parasitespecific pentapeptide insert in stabilizing the active conformation of the enzyme. FEBS J. 2015;282:2296-308.

41. Cohen S, Mc Gl, Carrington S. Gamma-globulin and acquired immunity to human malaria. Nature. 1961;192:733-7.

42. Delgado MF, Coviello S, Monsalvo AC, Melendi GA, Hernandez JZ, Batalle JP, et al. Lack of antibody affinity maturation due to poor Toll-like receptor stimulation leads to enhanced respiratory syncytial virus disease. Nat Med. 2009;15:34-41.

43. Douglas AD, Williams AR, Knuepfer E, Illingworth JJ, Furze JM, Crosnier C, et al. Neutralization of Plasmodium falciparum merozoites by antibodies against PfRH5. J Immunol. 2014;192:245-58.

44. Saul A. Kinetic constraints on the development of a malaria vaccine. Parasite Immunol. 1987;9:1-9.

45. Gilson PR, Crabb BS. Morphology and kinetics of the three distinct phases of red blood cell invasion by Plasmodium falciparum merozoites. Int J Parasitol. 2009:39:91-6.

46. Pal-Bhowmick I, Krishnan S, Jarori GK. Differential susceptibility of Plasmodium falciparum versus yeast and mammalian enolases to dissociation into active monomers. FEBS J. 2007:274:1932-45.

47. Brown CK, Kuhlman PL, Mattingly S, Slates K, Calie PJ, Farrar WW. A model of the quaternary structure of enolases, based on structural and evolutionary analysis of the octameric enolase from Bacillus subtilis. J Protein Chem. 1998:17:855-66.

48. Gandhi NS, Young K, Warmington JR, Mancera RL. Characterization of sequence and structural features of the Candida krusei enolase. In Silico Biol. 2008;8:449-60

49. Feng $Y$, Pan $X$, Sun W, Wang C, Zhang H, Li X, et al. Streptococcus suis enolase functions as a protective antigen displayed on the bacterial cell surface. J Infect Dis. 2009;200:1583-92.

50. Ghosh AK, Jacobs-Lorena M. Surface-expressed enolases of Plasmodium and other pathogens. Mem Inst Oswaldo Cruz. 2011;106(Suppl 1):85-90.

51. Hong J, Jianfa W, Jingru G, Yue L, Shuai L, Wenjin G, et al. Progress in biological functionsof alpha-enolase. Animal Nutrition. 2016;2:12-7

52. Liu K-J, Shih N-Y. The role of enolae in tissue invasion and metastasis of pathogens and tumor cells. J Cancer Mol. 2007;3:45-8.

53. Nogueira SV, Smith AA, Qin JH, Pal U. A surface enolase participates in Borrelia burgdorferi-plasminogen interaction and contributes to pathogen survival within feeding ticks. Infect Immun. 2012;80:82-90.

54. Pancholi V, Fischetti VA. Alpha-enolase, a novel strong plasmin(ogen) binding protein on the surface of pathogenic streptococci. J Biol Chem. 1998:273:14503-15.

55. Ord RL, Caldeira JC, Rodriguez M, Noe A, Chackerian B, Peabody DS, et al. A malaria vaccine candidate based on an epitope of the Plasmodium falciparum RH5 protein. Malar J. 2014;13:326.

56. Van der Straeten D, Rodrigues-Pousada RA, Goodman HM, Van Montagu M. Plant enolase: gene structure, expression, and evolution. Plant Cell. 1991:3:719-35.

57. Pabst O, Mowat AM. Oral tolerance to food protein. Mucosal Immunol. 2012:5:232-9.

58. Draper SJ, Heeney JL. Viruses as vaccine vectors for infectious diseases and cancer. Nat Rev Microbiol. 2010:8:62-73. 
59. Sheehy SH, Duncan CJ, Elias SC, Choudhary P, Biswas S, Halstead FD, et al. ChAd63-MVA-vectored blood-stage malaria vaccines targeting MSP1 and AMA1: assessment of efficacy against mosquito bite challenge in humans. Mol Ther. 2012;20:2355-68.

60. Milich DR, Hughes J, Jones J, Sallberg M, Phillips TR. Conversion of poorly immunogenic malaria repeat sequences into a highly immunogenic vaccine candidate. Vaccine. 2001;20:771-88.

61. de Cassan SC, Draper SJ. Recent advances in antibody-inducing poxviral and adenoviral vectored vaccine delivery platforms for difficult disease targets. Expert Rev Vaccines. 2013;12:365-78.

62. Miller LH, Hoffman SL. Research toward vaccines against malaria. Nat Med. 1998;4:520-4.

63. Malkin EM, Diemert DJ, McArthur JH, Perreault JR, Miles AP, Giersing BK, et al. Phase 1 clinical trial of apical membrane antigen 1: an asexual blood-stage vaccine for Plasmodium falciparum malaria. Infect Immun. 2005;73:3677-85

64. Roestenberg $M$, Remarque $E$, de Jonge $E$, Hermsen $R$, Blythman $H$, Leroy $\mathrm{O}$, et al. Safety and immunogenicity of a recombinant Plasmodium falciparum AMA1 malaria vaccine adjuvanted with Alhydrogel, Montanide ISA 720 or AS02. PLoS One. 2008;3:e3960.

65. El Sahly HM, Patel SM, Atmar RL, Lanford TA, Dube T, Thompson D, et al. Safety and immunogenicity of a recombinant nonglycosylated erythrocyte binding antigen 175 Region II malaria vaccine in healthy adults living in an area where malaria is not endemic. Clin Vaccine Immunol. 2010;17:1552-9.

66. Ellis RD, Martin LB, Shaffer D, Long CA, Miura K, Fay MP, et al. Phase 1 trial of the Plasmodium falciparum blood stage vaccine MSP1(42)-C1/ Alhydrogel with and without CPG 7909 in malaria naive adults. PLoS One. 2010;5:e8787.

67. Ogutu BR, Apollo OJ, McKinney D, Okoth W, Siangla J, Dubovsky F, et al. Blood stage malaria vaccine eliciting high antigen-specific antibody concentrations confers no protection to young children in Western Kenya. PLoS One. 2009:4:e4708.

68. Ockenhouse CF, Sun PF, Lanar DE, Wellde BT, Hall BT, Kester K, et al. Phase I/lla safety, immunogenicity, and efficacy trial of NYVAC-Pf7, a poxvectored, multiantigen, multistage vaccine candidate for Plasmodium falciparum malaria. J Infect Dis. 1998;177:1664-73.
69. Thompson FM, Porter DW, Okitsu SL, Westerfeld N, Vogel D, Todryk S, et al. Evidence of blood stage efficacy with a virosomal malaria vaccine in a phase lla clinical trial. PLoS One. 2008;3:e1493.

70. Douglas AD, Baldeviano GC, Lucas CM, Lugo-Roman LA, Crosnier C, Bartholdson SJ, et al. A PfRH5-based vaccine is efficacious against heterologous strain blood-stage Plasmodium falciparum infection in aotus monkeys. Cell Host Microbe. 2015;17:130-9.

71. Bustamante LY, Bartholdson SJ, Crosnier C, Campos MG, Wanaguru M, Nguon C, et al. A full-length recombinant Plasmodium falciparum PfRH5 protein induces inhibitory antibodies that are effective across common PfRH5 genetic variants. Vaccine. 2013;31:373-9.

72. Douglas AD, Williams AR, Illingworth JJ, Kamuyu G, Biswas S, Goodman $\mathrm{AL}$, et al. The blood-stage malaria antigen PfRH5 is susceptible to vaccineinducible cross-strain neutralizing antibody. Nat Commun. 2011;2:601.

73. Hayton K, Dumoulin P, Henschen B, Liu A, Papakrivos J, Wellems TE. Various PfRH5 polymorphisms can support Plasmodium falciparum invasion into the erythrocytes of owl monkeys and rats. Mol Biochem Parasitol. 2013;187:103-10.

74. Crosnier C, Bustamante LY, Bartholdson SJ, Bei AK, Theron M, Uchikawa $M$, et al. Basigin is a receptor essential for erythrocyte invasion by Plasmodium falciparum. Nature. 2011;480:534-7.

75. Payne RO, Silk SE, Elias SC, Miura K, Diouf A, Galaway F, et al. Human vaccination against $\mathrm{RH} 5$ induces neutralizing antimalarial antibodies that inhibit RH5 invasion complex interactions. JCI Insight. 2017;2:e96381.

76. Hayton K, Gaur D, Liu A, Takahashi J, Henschen B, Singh S, et al. Erythrocyte binding protein $\mathrm{PfRH} 5$ polymorphisms determine species-specific pathways of Plasmodium falciparum invasion. Cell Host Microbe. 2008;4:40-51.

77. Babbitt PC, Hasson MS, Wedekind JE, Palmer DR, Barrett WC, Reed GH, et al. The enolase superfamily: a general strategy for enzyme-catalyzed abstraction of the alpha-protons of carboxylic acids. Biochemistry. 1996;35:16489-501.

78. Verma M, Dutta SK. DNA sequences encoding enolase are remarkably conserved from yeast to mammals. Life Sci. 1994;55:893-9.
Ready to submit your research? Choose BMC and benefit from:

- fast, convenient online submission

- thorough peer review by experienced researchers in your field

- rapid publication on acceptance

- support for research data, including large and complex data types

- gold Open Access which fosters wider collaboration and increased citations

- maximum visibility for your research: over 100M website views per year

At BMC, research is always in progress.

Learn more biomedcentral.com/submissions 